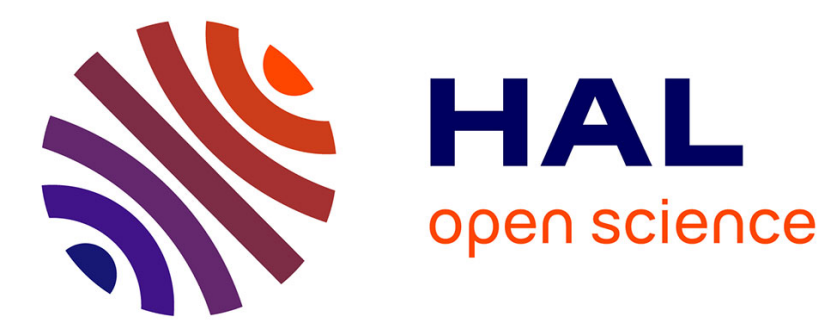

\title{
"I'm Just a Mathematician ": Why and How Mathematicians Collaborated with Military Ballisticians at Gâvre
}

David Aubin

\section{- To cite this version:}

David Aubin. " I'm Just a Mathematician ": Why and How Mathematicians Collaborated with Military Ballisticians at Gâvre. 2010. hal-00639895v1

\section{HAL Id: hal-00639895 \\ https://hal.sorbonne-universite.fr/hal-00639895v1}

Preprint submitted on 10 Nov 2011 (v1), last revised 23 Sep 2014 (v2)

HAL is a multi-disciplinary open access archive for the deposit and dissemination of scientific research documents, whether they are published or not. The documents may come from teaching and research institutions in France or abroad, or from public or private research centers.
L'archive ouverte pluridisciplinaire HAL, est destinée au dépôt et à la diffusion de documents scientifiques de niveau recherche, publiés ou non, émanant des établissements d'enseignement et de recherche français ou étrangers, des laboratoires publics ou privés. 


\title{
'I'm Just a Mathematician': Why and How Mathematicians Collaborated with Military Ballisticians at Gâvre
}

\author{
David Aubin
}

\begin{abstract}
This article examines the way in which mathematicians were led to contribute to ballistic studies in France during World War I. It pays special attention to the French Navy's Gâvre Experiments Commission first established in 1829, where university professor Jules Haag, military engineer Maurice Garnier and high school teacher Osée Marcus jointly developed a new method for computing ballistic trajectories (the so-called GHM method). It highlights the difficulties and successes encountered by mathematicians when they approached this military culture that already was mathematically sophisticated. It reviews briefly the history of ballistics at Gâvre before the First World War to understand the bitter feeling among artillerymen serving on the front about the inadequacies of their ballistic tables. In a final part, the technical contributions made by mathematicians, their experimental practices, and their effort for dissiminating their results are examined. This paper focuses on the role of several tensions between civilians and military science, betwen theory and experiment, between front and rear, etc. for undertanding the value of mathematicians' contributions to the war effort.
\end{abstract}

\section{Introduction}

On 18 September, 1915, Jules Haag (figure 1), a young professor of rational mechanics from the university of Clermont-Ferrand, wrote to his old mentor, Professor Paul Appell, in Paris. Mobilized in a non-fighting unit of the army, Haag was in charge of overseeing a workshop of the Michelin Tyre Company that produced ammunition for the celebrated $75-\mathrm{mm}$ cannon. Asked to compute ballistic trajectories for a new airplane bomb design called "bombe Michelin," he first tried, as he wrote,

1991 Mathematics Subject Classification. Primary 01A60; Secondary 65105, 70-03.

Key words and phrases. Ballistics.

In the writing of this paper, I used documents provided to me by Cécile Aguillaume, June Barrow-Green, Alain Carrière, Claudine Fontanon, Sébastien Gauthier, and Anne-Sandrine Paumier, whom I wish to thank here for their kind help. I would also like to thank the members of the WWI study group at the Institut de mathématiques de Jussieu, including Christian Gilain, Hélène Gispert, Catherine Goldstein, Laurent Mazliak, and Jim Ritter, as well as Patricve Bret and Pierre Mounier-Kuhn. This work was supported in part by the French Agence Nationale de la Recherche. 


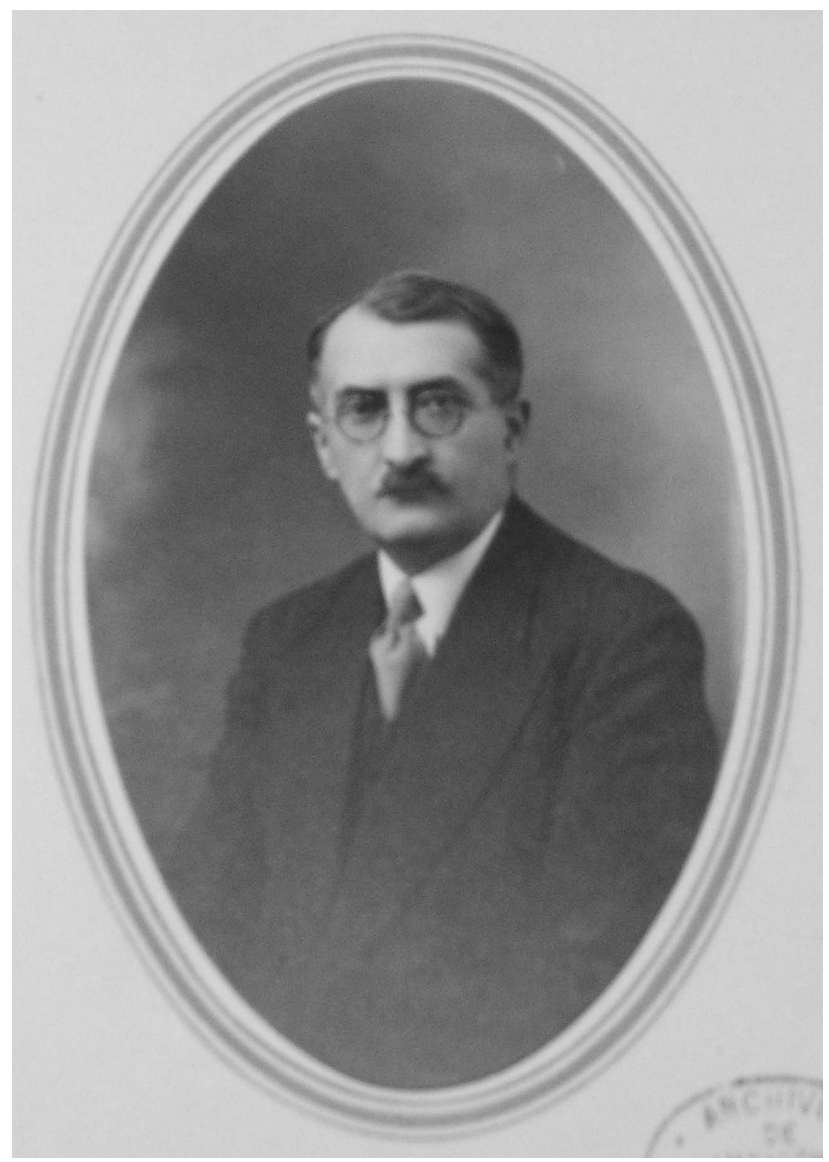

Figure 1. Jules Haag as correspondent to the Academy of Sciences. (C) Archives of the Academy of Sciences.

to apply "the artillerymen's classical methods." ${ }^{1}$ Having computed logarithms for three half-days in order to construct the required curves, Haag spent the little time he could spare to come try and improve to the methods. Rather surprisingly - since ballistics was after all sensitive matter that the Academy had expressly indicated it wanted to study further for the benefit of the French army-but luckily, as we will see, the short paper Haag wrote up and sent to Appell was published a week later in the Comptes rendus de l'Académie des sciences [hereafter CRAS] [Haag 1915a]. ${ }^{2}$

Characteristically for a scientist in the first months of World War I, Haag felt that his skills were not used to their fullest extent. His superiors apparently

\footnotetext{
1 "Les méthodes classiques des artilleurs." Haag to Appell, 18 September, 1915. Pochette de séance (27 September, 1915), Archives of the Academy of Sciences, Paris (hereafter AAS). All translations are mine.

${ }^{2}$ Two more papers on ballistics would then be published by Haag in the same year ([Haag 1915b] \& [Haag 1915c]). Some context about the work of the Michelin Company in WWI can be found in [Chapeaux 2006], p. 145-146. The first planes produced by Michelin (in collaboration with the Breguet company) were delivered in July 1915. On Jules Haag (1882-1953), see [Broglie 1953], [Mesnage 1953], [Châtelet \& Chazy 1956], \& [Meyer 1996].
} 
showed no interest in the results he was sending Appell: "In their eyes," Haag complained, "I am just a mathematician, without practical use other that serving as a computing machine when the occasion occurs." A mere sergeant [maréchal des logis], Haag had been barred from the local branch of the Commission of Inventions, since only officers (or civilians) could sit on it. $^{3}$ His only resort, he explained, was to study a bit of ballistics in his spare time and wish that one would let him devote more time to it. He admitted that this might have no immediate effect to help "drive out the Germans," but "the questions I am asked, without being told more about the mysterious studies that give rise to them" made him suspect that his contribution might indeed be directly pertinent to war effort. ${ }^{4}$

Less than a month later, on 12 October, 1915, the professional ballistician, General Prosper-Jules Charbonnier (1882-1936) (fig. 2) sent a memo to his superiors calling attention to the tremendous ballistic effort that war operations now demanded. A Navy officer trained at the École polytechnique who had served in Africa and in the Far East, Charbonnier was at the time President of the so-called Commission d'expériences d'artillerie navale de Gâvre, which was both a proving ground and the main military body in charge of ballistic computations for the French navy and army. In his memo, President Charbonnier explained that his overworked personnel were now unable to face the huge quantity of experiments and computations the war ministry asked them to carry out. Acknowledging that most artillerymen were of course otherwise busy on the battlefields, he noted that university professors possessed an "intellectual and professional training that would quickly make them useable by the Commission for computations and even experiments." A regular reader of the Comptes rendus, Charbonnier put forward Haag's name as a likely candidate. ${ }^{5}$ A fortnight later, on 29 October, 1915, the mathematician left Clermont-Ferrand to reach his new assignment post at Gâvre, near the seaport of Lorient in Brittany. ${ }^{6}$

As a result of Charbonnier's memo, a dozen mathematicians, physicists and astronomers would join the Gâvre Commission over the course of the war, including Albert Châtelet (1883-1960), Georges Valiron (1884-1955), Joseph Kampé de Fériet (1893-1982), and Arnaud Denjoy (1884-1974). The work they did at Gâvre was part of the establishment of new theoretical foundations for computing in exterior ballistics. New experimental methods for studying ballistics were also pursued, while the astronomer and future director of the Paris Observatory Ernest Esclangon (1876-1954) carried out much praised work on sound ranging, that is, the

\footnotetext{
${ }^{3} \mathrm{~A}$ promotion to the rank of second lieutenant [sous-lieutenant] in the artillery had indeed been considered in favor of Haag and rejected. On the Commission, see [Roussel 1989] as well as the contribution by David Aubin, Hélène Gispert and Catherine Goldstein to this volume.

4"Je ne suis, à leurs yeux, qu'un mathématicien, sans utilité pratique autre que celle de servir, quand l'occasion se présente, de machine à calculer"; "Cela ne serait peut-être d'aucune utilité pratique pour chasser les Allemands. Cependant, les questions qu'on me pose, sans m'initier davantage aux mystérieuses recherches qui les font naître, pourraient bien laisser supposer le contraire." All quotes come from letter from Haag to Appell, 18 September, 1915, my emphasis. Pochette de séance, 27 September, 1915, AAS. The misuse of scientific personnel at the start of World War I is a common theme among contemporary scientists and historians. For reviews, see [Kevles 1978], [Hartcup 1988], [Aubin \& Bret 2003], and references therein.

${ }^{5}$ Charbonnier to the minister (12 October, 1915), quoted in [Patard 1930, p. 274]. It is not known whether Charbonnier was in contact with Appell.

${ }^{6}$ See Haag's military file, Service historique de la défense, Armée de Terre [hereafter SHD:Terre], 6-Ye-17966.
} 


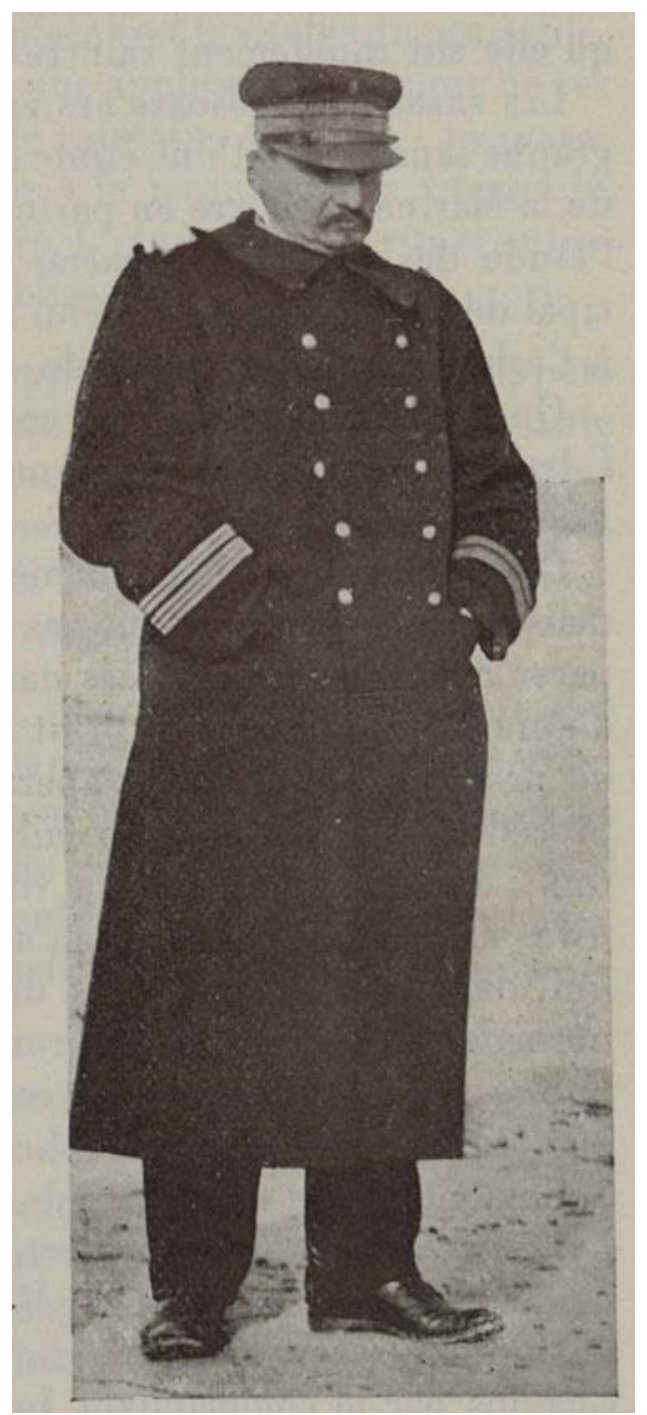

Figure 2. Colonel, later General Prosper-Jules Charbonnier pondering a ballistic problem on the beach of Gâvre, undated. (C) [Patard 1930], p. 253.

localization of enemy batteries by an analysis of the sound waves they emitted. ${ }^{7}$ Other prominent mathematicians such as Henri Lebesgue (1875-1941), (1871-1956) and Paul Montel (1876-1975) took part in ballistic research and enrolled several mathematics teachers in their effort.

Exterior ballistics was one of the few areas where French mathematicians truly were able, as mathematicians, to play a prominent part in World War I. My interest

\footnotetext{
${ }^{7}$ Although it properly belonged to the field of ballistics at the time, sound ranging will not be examined in detail here. On this topic, see esp. [Schiavon 2003a] \& [Schiavon 2003b]. See also [Jones 1921-1922], [Kevles 1969], \& [Palazzo 1999].
} 
in this paper is to examine the way in which young mathematicians such as Haag were drawn into military work at a time when the general belief was that there was no better way for them to contribute to the war effort than by fighting on the front. As the 22-year old Pierre Abeille wrote in his last letter to his parents:

Shame on intellectuals who fail to understand that they have [...] the sacred duty of putting their arms and chests in the same location as the arms and chests of their brothers [...]. To us, the privileged, the guardians of tradition, the transmitters of the Ideal, [the duty] of risking our lives and happily sacrificing ourselves for the preservation, the extension, the exaltation of all this beauty, of all this pride that we are the first to feel and to take advantage of. ${ }^{8}$

Historians have shown that in all belligerent countries the exact contours of research scientists' participation in the defense effort were far from being clearly delineated in 1914 and that many of them did not survive the first years of the war. ${ }^{9}$ Most historians' accounts of war work of mathematicians and scientists often, if not always, focus on the stories told by surviving scientists themselves. Most therefore view scientists' contributions on their own terms. But I would like to argue that to understand correctly the value of such contributions, it is necessary to widen the scope of our investigations. One needs to have a clear view of the military demands from the points of view both of general staffs and of men on the field. One also needs to pay special attention to the military technical structures that existed before the outbreak of the war to see why officers serving on these structures felt the need to enlist civilian expertise.

I want to argue that the incorporation of university mathematicians into military research structures was neither preordained nor straightforward. One may well argue that some mathematical knowledge has always been mustered in warfare. ${ }^{10}$ But before 1914 there also seems to have been a widespread feeling that professional mathematicians - that is, the university professors teaching and carrying out research in mathematics - had little to do with it. ${ }^{11}$

In the United States, Princeton University mathematician Oswald Veblen, despite his enthusiasm for war service, had difficulties to find a place where he could apply his mathematical skills. But he quickly found a befitting assignment at the Aberdeen Proving Ground, which was the U.S. counterpart of the Gâvre Commission. According to the internal history of this institution, "Exterior ballistics - that part of the science dealing with the behaviour of projectiles in flight - underwent

\footnotetext{
${ }^{8}$ A public servant, Sergeant Abeille had volunteered for active duty and was killed on 12 November, 1914, in Vingré, Aisne. His letter, dated 26 September, 1914, is repr. in [Foch 1922], p. 13.

${ }^{9}$ For France, see [Roussel 1989], [Aubin \& Bret 2003], \& [Galvez-Behar 2008].

${ }^{10} \mathrm{On}$ the history of mathematics and war, see among others [Mehrtens 1996], [Bernhelm Booß-Bavnbek \& Jens Høyrup 2003], and [Steele \& Dorland 2005]. On the WWI period especially, see [Siegmund-Schultze 2003].

${ }^{11}$ Even after the war, this feeling remained entrenched. A reviewer of a book on the history of ballistics ([Charbonnier 1928a]) — "the value of whose results I was able to appreciate for more than four years and the perfection of which I have known without joy," - expressed his surprise at encountering the names of the "greatest perhaps of the history of science: Galileo, Huygens, Newton, Euler, among others" [L.G. 1931, p. 376-377].
} 
a major revolution during World War I." ${ }^{12}$ Military historians in the U.S. easily acknowledged that scientists were major players in this revolution: Forest Ray Moulton, an astronomer from the university of Chicago, was the first head of the Ballistic Branch, and even though the computation of firing tables followed standard European procedures, their implementation and improvement were the work of three mathematicians linked to Princeton (Oswald Veblen, Gilbert Ames Bliss, and Thomas Hakon Gronwall). Although historians assessed that World War I had little effect on the postwar development of mathematics in the U.S., which remained characterized by the high value placed on abstractness, the field of ballistics appeared as a paradigmatic example of a research problem hitherto unsolvable by military structures and that only university scientists' special skills could solve. ${ }^{13}$ Likewise, the history of British ballistics has been centered on the scientist's figure, the team assembled by the Cambridge biophysicist Archibald Vivian Hill and involving the mathematicians John E. Littlewood, Edward Arthur Milne, and Ralph Howard Fowler, the last two being definitively turned away from prior involvement in pure mathematics. ${ }^{14}$

In France, by contrast, the situation seemed rather more complex and perhaps also more interesting. It was more complex because for a least a century most military officers had received their first academic training at the École polytechnique, before going on with their military officer's career. As a result, they often had the mathematical sophistication required for efficiently tackling the main problems of ballistics. Indeed French military ballisticians had a long acquaintance with the use of advanced mathematical techniques, but also physical and chemical theories and experimental procedures, to tackle every aspect of the problem of artillery firing. ${ }^{15}$ The French situation was also more complex because, as my opening suggests, many more mathematicians were involved almost from the start in ballistic research, joining various military institutions that already possessed a high degree of expertise that civilians - no matter how savant - did not necessarily have. The circumstances under which civilian, or formerly civilian, mathematicians were drawn to the problem and the specific contributions they were able to bring to it therefore need to be assessed from the point of view of the encounter of people coming from various parts. This encounter was forced upon them by the special circumstances of war and the specific demands that emerged from frontline fighting experience.

In the rear, mathematicians and ballisticians engaged in the production of range tables and computing procedures, which were hybrid entities straddling the various worlds of the fighting artilleryman, the military specialist, and the academic mathematician. In so far as it was a hybrid product hastily put together in a time of emergency, the new ballistics that came out of the First World War only difficultly found its place within institutional and epistemological frameworks after

\footnotetext{
${ }^{12}$ [U.S. n.d.], p. 3. The military work of American mathematicians is considered in the contribution by Deborah Kent, Della Fenster, and Thomas Archibald in this volume. On Veblen, see also the introduction to this volume. For contemporary assessments of American methods by the French, see [Schwartz 1927] and [Dodier \& Valiron 1927].

${ }^{13}$ For an assesment of the lack of effect of World War I on mathematics in the U.S., see [Parshall \& Rowe 1994, p. 444]. This view was nuanced in [Parshall 2000].

${ }^{14}$ See [Smith 1990] \& [Hill n.d.]. The war work of the Cambridge mathematicians is discussed in June Barrow-Green's contribution to this volume.

${ }^{15}$ On the École polytechnique, see the contribution of Jean-Luc Chabert and Christian Gilain to this volume.
} 
the Armistice. While military strategists insisted on the renewed importance of the artillery in modern warfare, there were persisting resistances to the complete transformation of ballistics into a branch of applied mathematics. From the early 1920s onward, civilian scientists were however associated to the Gâvre Commission on a permanent basis. Almost inexistent before the war, the relationship between university mathematicians and military research bodies was made permanent.

Seeing in the research bodies hastily put in place during the war by military as well as civil authorities a prefiguration of the state-controlled system of science funding that was fully developed during the Cold War, historians of science have mostly focused on the scientists' place in new organizations such as boards of inventions and research councils and turned a blind eye at older military research traditions. ${ }^{16}$ Our look at French ballistic research shows that scientists' involvement in these institutions in 1914-1918 resulted in their lasting association with military research structures that preexisted the start of the First World War and endure to this day. ${ }^{17}$

\section{Tradition, the Scientific Method and the "Gâvrais Virtues"}

Early in the 20th century, Gâvre was a small fishing village sitting at the tip of a long and thin peninsula that separates the harbour of Lorient from the Atlantic Ocean, on the south shore of Brittany. ${ }^{18}$ On the isthmus connecting it to the mainland, a proving ground was established in 1829, when the Gâvre Commission was created by the navy minister. The Commission was composed of military officers and engineers, coming in proportions that varied over the years from the naval, colonial, and sometimes land, artilleries. Its main objective was to carry out all types of research connected to gunnery, including experimentation with cannons, rockets and guns, with powder and with projectiles. Their effect on various types of steel plates was also investigated. But most of all, the Gâvre Commission was famous for its expertise in ballistics, both interior and exterior, both theoretical and experimental. Since its foundation its principal task was the confection of numerical tables giving the range as a function of the initial shooting angle (or line of departure) for each new cannon model introduced in the navy.

When he reached the Gâvre proving ground, Haag was hardly stepping into virgin territory. There, he and other civilian scientists found cannons of all sizes, cranes, railways, telegraphic and telephonic lines, chronographs and photographic cameras, all types of ballistic instruments needed to measure the initial velocity of projectiles, their power of penetration in steel plates, etc. (figure 3). But above all, they came into contact with a handful of navy officers who shared a strong scientific "ethos" attached to its own tradition and characterized by its own distinctive values. For mathematicians who were suddenly confronted with them, the "Gâvrais

\footnotetext{
${ }^{16}$ On Britain, see [MacLeod \& Andrews 1971], [Pattison 1983], and [Hull 1999]. On the U.S., see [Kevles 1968]. On France, see [Roussel 1989]. On Germany and Italy, see [Mehrtens 1996] \& [Epple et al. 2005]. A more detailed study of the Italian case is given in Pietro Nastasi and Rossanna Tazzioli's contribution to this volume.

${ }^{17}$ Let us note here that the successor institution of the Gâvre Commission, called GERBAM (Groupement d'études et de recherches balistiques, armes et munitions), was closed down on 1 January 2010. Only a naval training center for shooting now remains at the Gâvre polygon.

${ }^{18}$ After much debate, the standard usage today is to write Gâvres (with an $s$ at the end). At the time of the First World War, however, military officials had decided to use Gâvre which is much more common in contemporary documents. I will thus follow the latter usage.
} 


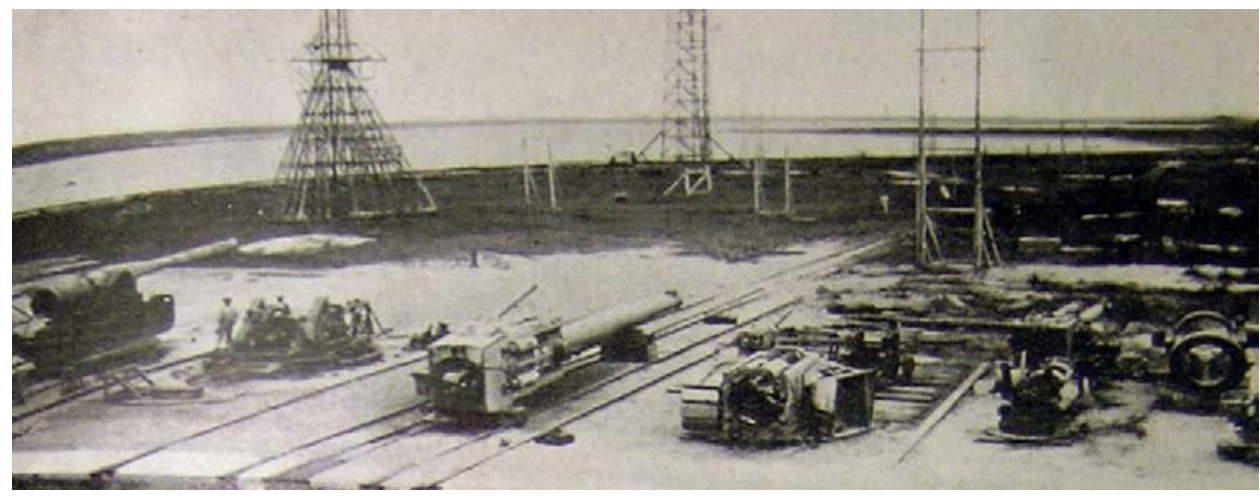

Figure 3. A view of the Gâvre polygon in the early 1930s.

virtues [les vertus gâvraises]," as Charbonnier called them, might at first have been discomforting [Charbonnier 1906, p. 425]. ${ }^{19}$ This is what Léon Patard, the official historian of the Gâvre Commission at the time he was its president, alluded to in the following passage written in 1930:

A success of the Naval Artillery during this war, and not the least, was the use of the good will of all these men, some of whom eminent savants but little prepared to their new role. Their trust had to be won; they had to be shown that, while they were not their equals in the domain of pure science, naval artillery engineers were able to understand their ideas, discuss their theories, and answer their objections. One can only infer the tact needed to subject them to long training courses in routine computing, to stem their professional attempts at perfecting computing methods as soon as they got there, to make them comply with the strict rules of experimentation and observation, and finally to lead them progressively from the role of auxiliaries to that of collaborators [Patard 1930, p. 279]. ${ }^{20}$

Charbonnier also insisted on the "scientific-technical" organization put in place at Gâvre, whereby collaborative work was done by "savants and officers." At Gâvre, "theoreticians remained in close and permanent contact with users" of cannons [Charbonnier 1929, p. 27-28]. Léon Lecornu (1854-1940), a professor of mechanics at the École polytechnique, hinted at something similar when he praised the fact that "several science professors transformed by mobilization into improvised artillerymen, brought a precious collaboration to the professionals: together they contributed for a large part to the final victory" [Lecornu 1924, p. 38].

Compare this emphasis on collaboration to scientists' accounts with which historians of science are much more familiar. The general tone used in the latter

${ }^{19}$ The Gâvre "virtues" may understood in relation with the scientific ethos was first popularized by [Merton 1942]. More recently, John Ziman suggested that the Mertonian ethos (which he calls cudos, for Communalism, Universality, Disinterested, Originality, Skepticism) might have coexisted with an industrial research ethos he called place (for Prioprietary, Local, Authoritarian, Commission, Expertise), which might be closer to the Gâvre ethos [Ziman 2000].

${ }^{20}$ Patard (1872-1963) was President of the Gâvre Commission from 26 January, 1925 to 20 February, 1931. 
makes them fall in one of two categories: while many are self-congratulatory and emphasize the unique contributions civilian scientists were able to bring to the war effort, many other are overfull with bitterness, resentment, and acrimony towards the military authorities' incompetence and their criminal misuse of the mathematicians' or of the scientists' special abilities. An instructive example of the second attitude can be found in the pamphlet privately published by the physicist and industrialist Georges Claude: "Our savants? Ah! if only you knew what was done of them! If only you knew their hopes, their efforts, their struggles, and in the end their powerlessness" [Claude 1919, p. 33]. ${ }^{21}$ By contrast, Patard underscored the difficulty faced by the military members of the Gâvre Commission when they endeavoured to integrate civilian scientists to their working procedures. Although Haag was asked to partake in the solution of a new problem (anti-aircraft gunnery) and in the process introduced new mathematical methods at Gâvre (error analysis), the main problem, as Patard saw it, laid in containing scientists' impatience, acquainting them with the Gâvre tradition and making them comply with entrenched working procedures.

Some scientists seemed to have been quite aware of the fact that they were stepping on other experts' turf when they offered their help to military engineers. The physicist Aimé Cotton (1869-1951) was an established physicist and already recognized by military officials for having developed, in collaboration with Pierre Weiss (1865-1940), one of the most successful instuments used in sound ranging. In 1916, Cotton wrote General Hubert Gossot (1853-1935), a former president of the Gâvre Commission, to offer his help on the problem of determining the effect of weather conditions on artillery fire. It is interesting to note the very cautious wording used by Cotton in his letter: "if you judge that the reflections of a physicist who is perforce incompetent on many points may be of some interest to you, I put myself at your disposal to extract from them results that would seem useable and to give them [the results] a form more easily applicable in practice (relying on the advices of men of the trade)." ${ }^{22}$ Clearly, rather than assuming that he knew better, the physicist placed himself at the disposal of the military and not merely of his country.

Tradition at Gâvre was no empty rhetoric. It was the bedrock of its scientific credibility. One is struck not only by the palimpsest-like manner in which the history of the Gâvre Commission has been written and rewritten on several occasions by some of the major ballisticians who worked there, but also by the insistence put on tradition despite important breaks in the methods and despite rapid changes in the gunpowder and materials used by artilleries. ${ }^{23}$ As Charbonnier wrote in 1906, Gâvre was characterized by its special virtues: "respect for the continuity of doctrines, freedom of thought, faith in experimentation, [and] patience

\footnotetext{
${ }^{21}$ On Claude, see [Aubin 2003] and [Baillot 2010].

22 "Si vous estimez que les réflexions d'un physicien, nécessairement incompétent sur bien des points, présentent quand même quelque intérêt, je me mets à votre disposition pour en extraire les résultats qui paraîtraient pouvoir être utilisés et leur donner une forme plus facile à appliquer pratiquement (en m'aidant des conseils des gens du métier)." Cotton to Gossot, 8 February, 1916, SHD:Terre, 2W292.

${ }^{23}$ Besides [Charbonnier 1906] and [Patard 1930] already cited, other insider's histories of Gâvre are: [Poyen-Bellisle 1889-1893] and [Crémieux 1930]. Secondary literature about the Gâvre Commission is however much rarer, but see [Bru 1996], [Seddik-Ameur 2003], and [Mounier-Kuhn 2010, 194-195]. On ballistics in France more generally, see also [Belhoste 1990] and [Fontanon 2005].
} 
for long computations and for careful verifications" [Charbonnier 1906, p. 425426]. Another ballistic engineer, Maxime Crémieux would concur in 1930: "beyond all experimental and theoretical investigations, one senses a working method that presided over the whole [...]: submission to experimental facts, scientific probity, respect of tradition, minute consideration of details, clarity of deductions, freedom in technical opinions" [Crémieux 1930, p. 145].

Let us be more specific: although it has remained in the shadows of more public institutions, like observatories and laboratories, or institutions recently studied in more details, like factory workshops, Gâvre was one of the main theaters for the development of strict experimental procedures in the nineteenth century. Indeed, it is probably no exaggeration to say that it was one of the places where modern procedures for the mathematical and quantitative testing of theories against experiments were designed and experienced with on a large scale. ${ }^{24}$ In ballistics, the comparative merits of empiricism and theory were often discussed explicitly. Like the observatory, it played a front part in the slow convergence between empirical procedures and theoretical approaches derived from Newton's first principles. "While mathematicians subsequent to Cauchy were usually more interested in proofs of existence and in functional relations among solutions obtained, than in numerical results, there were already cultivated two fields which especially called for numerical methods, namely astronomy and ballistics" [Bennett et al. 1956, p. 61]. While one may contest Bennett's view of mathematicians on the ground that the latter did manifest some interests in favor of computation, one cannot deny the importance of astronomy and ballistics for the history of computing.

After the establishment of the Gâvre Commission, it was the professor of hydrology at the Lorient Naval School, Félix Hélie (1795-1885), who soon assumed the scientific leadership. Starting in 1834, after the summers which were devoted to experimentation and cannon testings, Hélie would alone carry out all the computations needed to interpret the experimental results and draft all the reports sent to the navy ministry. A staunch empiricist, he distrusted theories developed from first principles, which gave poor results when tested on the proving ground. Charbonnier thought that, in his work, Hélie showed more patience than originality [Charbonnier 1906, p. 413]. In Hélie's mind, every new range table had to be established through extensive experimental work, and the laws and formulas derived from this massive work could hope for no more than an ephemeral existence. In his Traité de balistique expérimentale, Hélie developed his method: summarize experimental results by a mathematical formula as simple as possible that should not be applied outside of the experimental limits used to derive it. He opened this treatise with the following words:

The principles of rational mechanics are not sufficient to solve [all the questions relative to artillery shooting and its effects]; the forces and resistances at play can only be appreciated through observation. A treatise on ballistics must therefore be in a large part composed of descriptions and discussions of experiments whose result often are the only possible demonstration for the

\footnotetext{
${ }^{24} \mathrm{On}$ the role of the military in scientific research in France in the period preceding the establishment of the Gâvre Commission, see [Bret 2002]. For studies on the history of observatory techniques in the 19th century, see [Aubin et al. 2010].
} 
propositions which one may consider as having been established

$\left[\right.$ Hélie 1865, p. 1]. ${ }^{25}$

Hélie's attitude may in part be explained by the fact that, compared to academic settings, the Gâvre Commission was never allowed to lose sight of its practical mission: to produce the knowledge necessary for aiming guns accurately. So, even when later ballisticians expressed the wish to revalue the role of theory in their field (see below p. 815), they came up with stringent criteria. ${ }^{26}$ According to the Gâvre ballisticians, a theory was judged satisfactory only in so far as it could be checked numerically, even if this entailed a considerable amount of work [Charbonnier 1906, p. 432]. According to Crémieux, the Gâvrais character was shaped in this period and entailed an "absolute respect" for carefully documented experimental results and repugnance towards erasing disagreement between theory and experiments. On the contrary, all discordances had to be underscored in written reports so that one knew exactly where methods were in need of improvement [Crémieux 1930, p. 149]. This was, Charbonnier insisted, the application of Francis Bacon's method, which led to practical prescriptions: (1) never to fire a useless shot; (2) never to fire a necessary shot without having first computed all experimental results expected from it; and (3) "perform all experiments necessary in the toughest circumstances, that is such that disagreement between theory and experiment has the greatest chance of manifesting itself." 27

For theory considerations to be put in practice, he added, three precautions were required:

(1) compute all necessary tables in full, without disdainfully leaving this vulgar care to technicians [praticiens];

(2) provide full and detailed numerical examples;

(3) prepare with great care computation skeletons, which can be lithographed and whose columns are merely left so to speak to be filled out numerically. $^{28}$

In short, Charbonnier wrote, the Gâvrais character could be summarized as such: "a very practical outlook [...] which holds a theory as satisfactory only in so far as it has been numerically checked, compared to all the known experiments, and when necessary numerical tables have been computed often at the price of considerable and off-putting labour an idea of which only those who have themselves executed similar task can have" [Charbonnier 1906, p. 432].

In 1915, procedures followed by the Gâvre Commission therefore were particularly stringent. They were solutions adopted over the course of almost a hundred years of confrontation with intricate problems and practical demands from fighting artillerymen on ships around the world. If these procedures insured the international high regard in which results coming out of the Gâvre were held, "doctrinal" thinking, the requirements of efficiency, and respect for hierarchical also rigidified procedures. Once adopted after extensive series of tests, computing procedures were

\footnotetext{
${ }^{25}$ On Hélie, see [Delauney 1892] and compare with the history of ballistics at Metz in [Bru 1996].

${ }^{26}$ Note that this was not only felt at Gâvre. See the way in which an engineer in the artillery branch of the Creusot Factories argues in favor of theory and for the insufficiency of experiments alone in [Morel 1904], p. 7.

${ }^{27}$ [Charbonnier 1906], p. 417. One should here be reminded that in the course of the 19 th century it became increasingly expensive to fire a cannon shot.

${ }^{28}$ [Charbonnier 1906, p. 432n].
} 
rarely changed and often after much debating. To understand what was at stake in theoretical and practical ballistics at the time when Haag and his colleagues reached the Gâvre peninsula, let us now briefly review the status of exterior ballistics at that time.

\section{Exterior ballistics before 1915}

Ballistics is a complex science where theoretical, experimental, and computational uncertainties always clashed with one another. Moreover, technological innovation in cannon and projectile design sometimes increased the complexity of the problem. The first complication to consider came from the fact that the motion of a projectile actually involves two very different sets of problems: interior ballistics, which deals with what happens inside the cannon muzzle, can be tackled mostly by mobilizing the tools of thermodynamics and chemistry, and exterior ballistics which is foremost a mechanical and mathematical problem. Both problems moreover require some input from fluid mechanics. It is a remarkable fact that up to WWI, and beyond, military ballisticians would address both interior and exterior ballistics, often with an equal degree of competency.

Restricting our attention to exterior ballistics, while the laws of dynamics easily allowed to state the differential equations governing the trajectory of a projectile through air, various effects combined to make its general solution very hard to find. At the beginning of the 20th century, Charbonnier drew inspiration from astronomical methods to introduce a useful distinction that considerably simplified the presentation of exterior ballistics [Charbonnier 1907]. ${ }^{29}$ "Secondary" problems, as he called them, were considered perturbations to the "principal" problem. They were supposed to take into account the effects of the wind, of variations in atmospheric temperature and pressure, of the wear of the piece, of the projectile's spin around its axis, of the earth's rotation, etc. The principal ballistic problem therefore amounted to solving an ordinary differential equation, called the "hodograph," whose simplest form was:

$$
d v_{x}=\frac{c v}{g} F(v) d \tau
$$

where $v$ is the magnitude, and $v_{x}=v \cos \tau$ the horizontal component, of the velocity $v$ of the projectile in the $(x, y)$-plane, expressed as a function of the uniformly decreasing angle $\tau$ with respect to the horizontal at each point of the trajectory (figure 4); $g$ is the acceleration due to gravity at the surface of the earth (taken in first approximation to be constant); $c$ the so-called "ballistic coefficient" (varying according to the size and shape of the projectile); and $F(v)=f(v) / v^{2}$ the law of resistance of the air to the motion of the projectile supposed in first-order approximation to be a function of $v$ only. ${ }^{30}$

\footnotetext{
${ }^{29}$ Many publications give the state of the art in the first decade of the 20th century; see, e.g.: [Gilman 1905] and [Cranz \& Vallier 1913].

${ }^{30}$ Because of its great simplicity, I adapt here Charbonnier's own presentation in [Charbonnier 1929]. Note however that he also included as another factor the air density $H(y)$ that prior to WWI was generally taken to be a constant in the principal ballistic problem (corresponding to low altitude trajectories). When vertical differences in air density were taken into account (as a secondary problem), an exponential law $H(y)=e^{-h y}$ was usually assumed. A very similar, equivalent expression is found in [Charbonnier 1906], p. 449.
} 


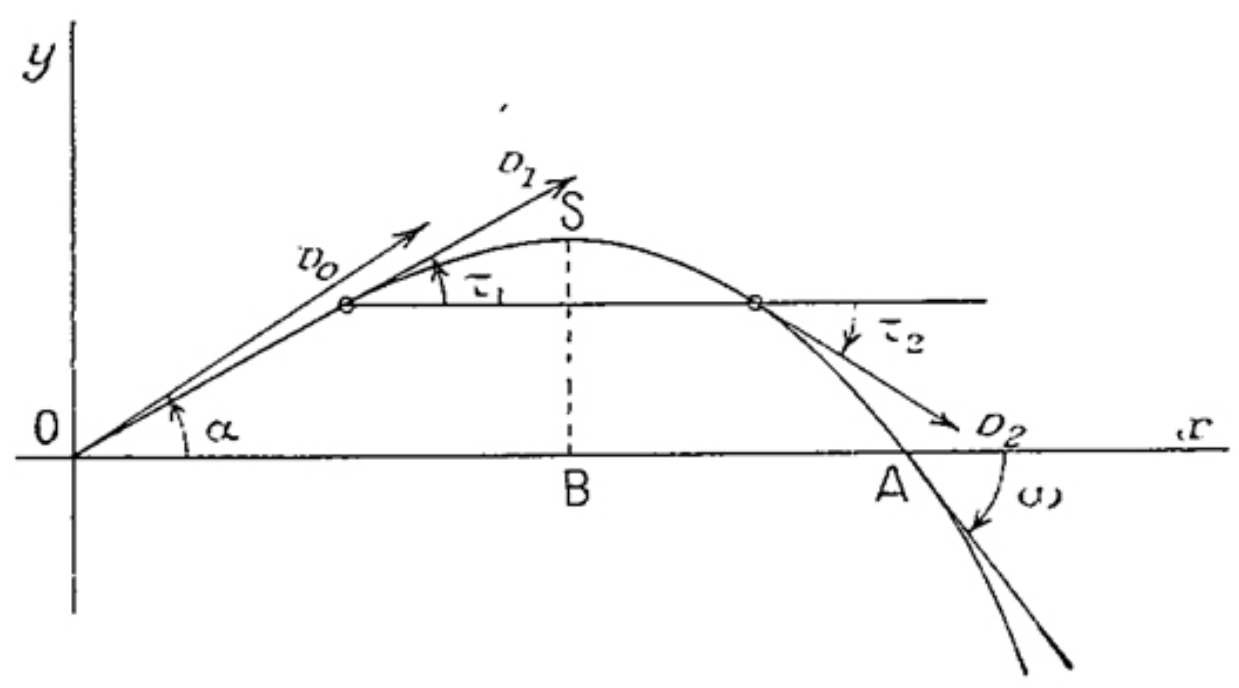

FIGURE 4. Schematic representation of the hodograph

The principal ballistic problem is therefore mathematically equivalent to finding the solution (or at least a fairly accurate approximation of certain quantities derivable from the solution) to an ordinary differential equation involving some unknown functions. Issues connected to the resolution of the principal ballistic problem were of three sorts: (1) how to compute the ballistic coefficient $c ;(2)$ what was the exact forms of the air resistance function $F(v)$; and (3) in case these quantities gave rise to differential equations that were insoluble by formal means what was the best method for finding a good approximation to the solution? Although at first sight the former two questions would seem to be soluble by the tools of fluid mechanics and the latter to be purely a mathematical problem, all questions were intertwined, a fact that can be illustrated by recalling that in the first experiments carried out by the Gâvre Commission, before the ballistic pendulum was introdued there, initial bullet velocities were essentially determined by measuring the range of their trajectories! $!^{31}$

2.1. Ballistic Coefficient and Air Resistance. At the beginning of WWI, the Gâvre Commission had under Charbonnier's leadership adopted a theoretical framework and strict computational procedures for dealing with exterior ballistics. If the practical needs of the artillery were thereby met by the Gâvre savants any unforeseen innovation modifying shooting parameters would immediately throw ballisticians into uncharted territories. For most purposes, reliable results seemed to be obtained using the following formula for the ballistic coefficient:

$$
c=\frac{i \Delta_{0} a^{2}}{p}
$$

\footnotetext{
${ }^{31}$ Invented by Benjamin Robins in the 18th century, the ballistic pendulum was greatly improved by the ballisticians of the Metz Artillery School, Guillaume Piobert, Arthur Morin, and Isidore Didion in the 1840s ([Didion 1860], p. 321-326 and [Morin \& Tresca 1860], vol. 1, p. 228-233). It was adopted by the Gâvre Commission in the same decade. On the Metz artillery school, see [Belhoste \& Picon 1996].
} 
where $\Delta_{0}$ was the air density on the ground ; $a$ and $p$ respectively the calibre and the weight of the projectile and $i$ its "form factor" often considered proportional to $\sin \gamma$, with $\gamma$ the penetrating angle at the tip of the projectile. But all attempts at securing a theoretical foundation for this formula remained elusive.

As far as the resistance law was concerned, ballisticians first used the Newton resistance law proportional to the square of the velocity $\left(v^{2}\right)$. When riffled barrels were introduced, initial speeds greatly increased and the Alexandre-Hippolyte Piton-Bressant (1820-1847) resistance law (proportional to $v^{4}$ ) was adopted for a while. $^{32}$ In the second half of the century, smokeless powder increased again initial projectile speed. New extensive series of experiments were carried out in the 1860s by Nikolai Maievski near Saint-Petersbourg in Russia and by Francis Bashforth with the help of his electric chronographs in Woolwich England. In the next decades, new evidence from experiments performed from 1879 onward by the Krupp Company on the Meppen shooting range in Germany and by Colonel Hojel in Holland in 1884 showed that the resistance law decreased at higher velocity. As a result the functional form of the law became tremendously complicated. In Italy, Francesco Siacci (1839-1907) suggested the following expression [Cranz \& Vallier 1913, p. 16]:

$$
F(v)=0.2002 v-48.05+\sqrt{(0.1648 v-47.95)^{2}+9.6}+\frac{0.442 v(v-300)}{371+\left(\frac{v}{200}\right)^{10}}
$$

In 1896, an empirical resistance law was adopted at Gâvre: the famous "fonction de Gâvre." Thousands of numerical results, derived from firing tests with initial speeds from 400 to $1200 \mathrm{~m} / \mathrm{s}$ with all calibres and all types of projectiles were used to determine this function which was presented as a table, as a graph, and, finally, as an analytic expression introduced by chef d'escadron Demogue [Crémieux 1930, p. 152]. ${ }^{33}$ According to $\mathrm{Haag}^{34}$, the function used during WWI had the following form where the exponential term was introduced by the naval engineer Maurice Garnier:

$$
F(v)=v^{2}\left[0.255+\frac{\sqrt[4]{1+0.0392\left(\frac{v-300}{500}\right)^{8}}}{27,226+494\left(\frac{v-330}{50}\right)^{2}} \arctan \frac{v-330}{50}\right] \exp \left(\frac{v-600}{10^{6}}\right)
$$

\footnotetext{
${ }^{32}$ Many other laws $f(v)$ were suggested and used in the 19 th century: $b v^{3}$ by Bashforth; $a v^{2}(1+b v)$ by Saint-Robert; $a v^{2}\left(1+b v^{2}\right)$ by Didion; $a+b v$ by Chapel, etc. See [Charbonnier 1906], p. 444. A short and simple mathematically-oriented introduction to the question of air resistance is to be found in [Long \& Weiss 1999].

${ }^{33}$ The resistance law was first expressed as a numerical table and presented in reports nos. 1414 and 1429 of the Gâvre Commission (14 March and 21 July, 1896), giving log $f(v)$ or $\log \left[f(v) / v^{2}\right]$ for values of $v$ from 0 to $1200 \mathrm{~m} / \mathrm{s}$; see Table I1 in [Gâvre 1916, p. 3-6], SHD:Terre 2W292; "Tableaux nécessaires au calcul des trajectoires par arcs successifs" SHD:Terre 2W292; and [Bingen 1928, p. 20-22]. One finds a graphic representation of the laws and the various experimental trials that led to it in [Cranz \& Vallier 1913, p. 17].

${ }^{34}$ [Haag 1921], p. 3. Note that there is a mistake in this function. To reproduce the numerical data in published tables, the coefficient of the arctangent, and this one alone, should be multiplied roughly by a factor of 3500 .
} 
2.2. Siacci's Direct-Fire Approximation. Eschewing simple power laws for the air resistance often meant that resulting differential equations became intractable by formal methods. ${ }^{35}$ Two type of approximation methods were used by the Gâvre Commission: (1) step-by-step integration methods [in French, calcul des trajectoires par arc], and (2) approximations derived using the "direct-fire" assumption [in French "tir de plein fouet"]. Let us review how they were successively adopted by the Gâvre Commission for the computation of firing tables.

Step-by-step integration methods, which French ballisticians called the "arc method," dated back to Leonhard Euler (1753). ${ }^{36}$ In this approach, the equation was solved on a small interval only assuming that the air resistance was quadratic over the interval. Interest in these methods was given a boost when the second edition of Hélie's treatise was published in $1884 .{ }^{37}$ After the French-German War and the death of Hélie in 1887, the "struggle engaged between traditionalism and progress was vigorously undertaken" [Charbonnier 1906, p. 416] and ballisticians at Gâvre adopted a more theoretical approach. The second edition of the treatise received significant contributions from the polytechnician mathematical physicist Pierre-Henry Hugoniot (1851-1887) whose inclination for mathematical theories was much greater than Hélie's. ${ }^{38}$ While the work of Bashforth and George Greenhill in Britain, of Francesco Siacci (1839-1907) in Italy and of Carl Cranz (1858-1945) in Germany was renewing the field of ballistics, Hélie and Hugoniot showed that old step-by-step methods could be as accurate as desired, provided intervals chosen were numerous and small enough [Hélie \& Hugoniot 1884, vol. 2, p. 289].

After Hugoniot's untimely death in 1887, Hubert Gossot, also a graduate from the École polytechnique (1874) who had joined the naval artillery corps, took over the Gâvre Commission. ${ }^{39}$ In 1887 and 1888 he used the method to compute firing tables for new 34- $\mathrm{cm}$ and $90-\mathrm{mm}$ caliber cannons. At long last, the Gâvre Commission had mastered a method for computing firing tables that was safe, accurate, and dependable. But it also was time consuming and, many felt, inelegant: it was "a computing process, not a theory" [Patard 1930, p. 243].

The Commission thus consented to submit itself deliberately and for many long years to the boredom of very long, very fastidious and very inelegant computations using the step-by-step method

\footnotetext{
${ }^{35}$ During the war, several mathematicians studied conditions to be imposed on $F(v)$ in order for the hodograph to remain integrable. This is point 2 in the report on ballistics drafted after the war [Hadamard 1920]. Jules Drach suggested a method using Galois theory in 1914. Arnaud Denjoy wrote a report about this method while he was at the Gâvre Commission in July 1917. For more on this, see [Drach 1914], [Drach 1920]. See also the note written by Paul Montel in [Charbonnier 1927, vol. 1, p. 498-515]. Several notes and letters concerning Denjoy's role are to be found in the "Ballistics" file of the "Commission nommée pour l'étude des questions la défense nationale," AAS.

${ }^{36} \mathrm{On}$ the early history of exterior ballistics, see [Charbonnier 1929], [Hall 1952], [Steele 1994], as well as [Tournès 2010].

${ }^{37}$ Note that while the second edition of the treatise was published by the two authors [Hélie \& Hugoniot 1884], the first one had only one [Hélie 1865].

${ }^{38} \mathrm{On}$ the life and work of Hugoniot, see [Chéret 1990]. A clear offshoot of his ballistic studies, Hugoniot's seminal paper on shock compression was published in two parts in the Journal de l'École polytechnique in 1887 and 1889.

${ }^{39}$ On Gossot, see [Challéat 1933-1935], vol. 2, p. 314 and SHD:Terre 11-Yd-47. Gossot later was Central Director of Naval Artillery (1905-1909) and Inspecteur des études et expériences techniques de l'artillerie from July 1915 to 1917.
} 
[...] because it understood what were the consequences of its liberation from empirical methods and of the return of ballistics back to its natural source: possibility a priori computing any trajectory from any cannon; extreme reduction of ballistic shots needed to establish a firing table; [...] exact determination of non observed elements of the trajectory ([Charbonnier 1906, p. 423]; quoted in [Patard 1930, p. 243]).

A second group of methods were concurrently developed for approximately solving the hodograph. The most successful was introduced in 1880 by Siacci whose treatise was quickly translated into French. The principle of the method was to replace the velocity $v$ by a pseudo-velocity $u$ defined as [Siacci 1892, p. 47]:

$v \cos \tau=u \cos \alpha$

where $\alpha$, called the angle of projection (or line of departure), corresponded to the actual initial shooting angle. ${ }^{40}$ The pseudo-velocity was equal as the velocity only at the origin and in the descending branch of the trajectory when $\tau=-\alpha$, but in the case of direct fire when the angle $\tau$ was close to zero over the whole trajectory, the difference between velocity and pseudo-velocity also remained small. Writing the hodograph equation in terms of the pseudo-velocity $u$, Siacci found a general equation for the trajectory [Siacci 1892, p. 49]:

$$
y=x \tan \alpha-\frac{g x^{2}}{2 V_{0}^{2} \cos ^{2} \alpha} G\left(\frac{x}{c}\right),
$$

where $G$ was a function that depended on the air resistance law $F(u)$ that was adopted, but that could be computed, provided four secondary functions $J(u)$, $S(u), D(u)$ and $A(u)$ defined as follows were computed and tabulated for every value of $u$ :

$$
\begin{aligned}
J(u) & =-g \int \frac{d u}{u F(u)} & D(u) & =-\int \frac{u d u}{F(u)} \\
S(u) & =-\int \frac{d u}{F(u)} & A(u) & =-\int \frac{u J(u) d u}{F(u)}
\end{aligned}
$$

Using the tabulated values of these functions, most elements of a trajectory could be computed rather quickly, typically in less than twenty to thirty simple operations. For example, given the value of the pseudo-velocity $u$ at a point on the trajectory and the initial velocity $V_{0}$, the $x$-coordinate of the projectile was simply given by the formula $x=C\left[D\left(V_{0}\right)-D(u)\right]$, for a certain constant $C$. Siacci also relied on the assumption that a certain variable $\beta$ was constant and equal to 1 . Under this assumption, the results computed using Siacci's method remained relatively reliable in the case of direct fire, that is, provided $\alpha<20^{\circ}$ [Charbonnier 1907].

To compute deviations due to secondary problems such as the rotation of the projectile or wind, a few other secondary functions were required, all of which were computed and tabulated. Written by the ballistician Anne, Gâvre reports from 23 December, 1912, and 28 July, 1913, contained the required tables. Having joined the

\footnotetext{
${ }^{40}$ Note that Siacci used $\theta$ instead of $\tau$ and $\varphi$ instead of $\alpha$.
} 
Gâvre Commission in 1907, Anne died in October 1921, "worn-out by the exhausting labor he was submitted to during the war" [Patard 1930, p. 293]. This extensive computing effort was completed and printed in January 1916 [Gâvre 1916]. By that time, however, war had made them obsolete!

\section{The Mathematical War Viewed from the Front}

"One of the surprises of the present war," the ballistician Emmanuel Vallier (18491921) from the Academy of Sciences wrote in May 1915, "certainly is the great development of indirect fire" [Vallier 1915, p. 297]. Few indeed had foreseen the tremendous change of fortune artillery - and as a result ballistics - would undergo during WWI. To understand the evolution of problems and solutions considered worthwhile at Gâvre, one needs to take into account fighting soldiers' reaction to what the Commission had to offer. While it struck the "everyman at war" that mathematics played a crucial part in his predicament, the way this was translated in practice hardly is straightforward. ${ }^{41}$ Indeed, the very usefulness of the mathematical apparatus for ballistics was drastically questioned. Due to the rapid evolution in the tactic and strategic use of artillery, commanding officers immediately found that mathematical support for directing fire was imprecise, confusing, or simply lacking. At the hostilities' outbreak, there even seemed to have been a widespread sentiment among artillerymen that as a practical science mathematical ballistics had failed them and a "conflict arose between artillerymen and their [firing table] suppliers" [Boissonnet 1920, p. 36].

At a strategic level, it was quickly realized that artillery was to play a major role in this war. Less than a week after the declaration of war, Captain Lombal observed that the standard 75-mm cannon adopted by the French Army in 1897 (fig. 5) was unexpectedly deadly. With just 16 shots fired on 7 August, 1914, he estimated he had taken down 600 to 700 German cavaliers. Some computed that this amounted to one dead per kilo of explosive - and marvelled at such a high return! ${ }^{42}$

Among the first "lessons" drawn from the emergence of scientific warfare was the conviction that heavy artillery now played a much bigger role than expected (see, e.g., [Bos 1923] and [Rouquerol 1920]). Following General Hippolyte Langlois's doctrine, the French Army had hitherto emphasized the auxiliary role of artillery with respect to infantry in open warfare. A regulation of 1913 that is often quoted stated: "artillery does not prepare the attacks, it supports them." ${ }^{43}$ Despite the success of "the little Frenchman" as the light rapid-firing 75-mm cannon was sometimes called [Sainean 1916, p. 145], in 1914 the French troops' morale greatly suffered from the German domination in terms of heavy artillery. Shell shock was

\footnotetext{
${ }^{41}$ This alludes to British Private Edgar Norman Gladden's feeling that this was a "war of guns and mathematics" [Gladden 1930, p. 121]. See the introduction to this volume by David Aubin and Catherine Goldstein.

${ }^{42}$ [Gascouin 1920, p. 78-81]. On the 75- mm cannon, literature is abundant; see especially an early praise [Houllevigue 1914], and more informed studies in [Challéat 1933-1935, vol. 2, p. 338-364] and [Rouquerol 1919, p. 58-77].

43 "L'artillerie ne prépare pas les attaques, elle les appuie" (quoted in [Gascouin 1920, p. 56]). For the French combat doctrine before WWI, see [Percin 1914, p. 165], and [Foch 1903, p. 314]. This doctrine was by and large based on [Langlois 1892] and [Langlois 1906]. On Langlois, see [P.N. 1907], [Glück 1919], and [Ripperger 1995]. For contrary opinions expressed just before the outbreak of WWI, see [Herr 1913] and [Rouquerol 1914].
} 


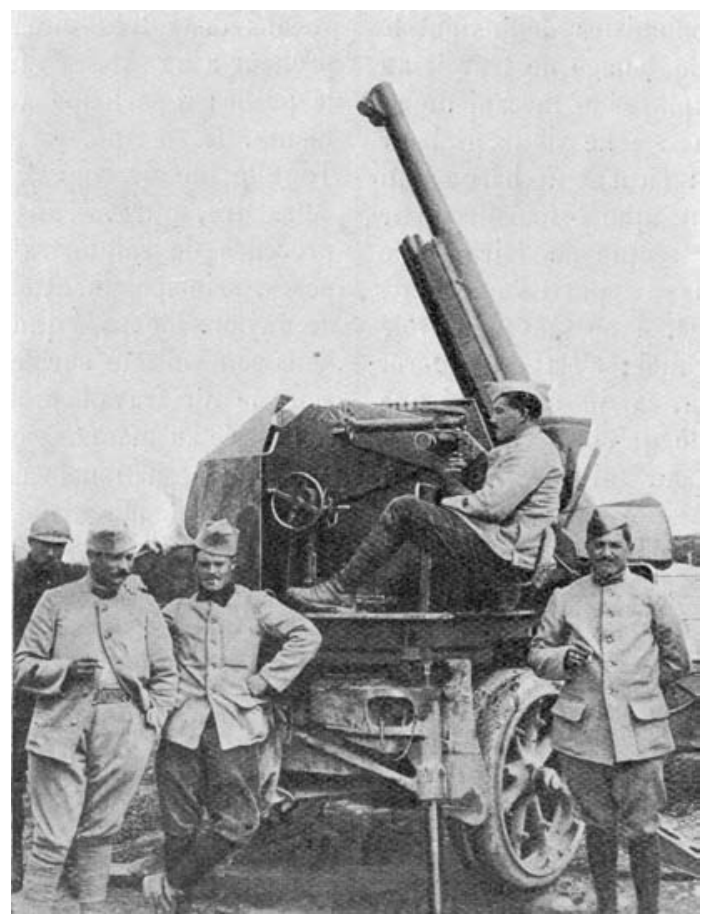

FiguRE 5. The celebrated 75-mm cannon of the French field artillery, here adapted for anti-aircraft shooting. Note the highangle of shooting. Source: La Nature 44-2 (1916), p. 135.

made worse by the evidence that the long range of German guns kept them out of the reach of their French counterparts which were overwhelmed, too few in numbers, and generally outdated. The President of the Republic, Raymond Poincaré, lamented the lack of cannons and ammunition. Marshall Ferdinand Foch himself underscored the inefficiency of the $75 \mathrm{~s}$ for indirect fire. In this domain as well as in many others, unpreparedness seemed appalling not only to military officers but in the eyes of some astute civilian observers as well. ${ }^{44}$ What made this realization even more painful was the fact that it had been discussed at length in artillery circles just before the war. ${ }^{45}$ In haste, naval artillery and siege cannons were brought to the frontline and positioned on terrains they had not been designed to occupy. As is well known, new material was ordered en masse. In May, the socialist member of Parliament Albert Thomas was put in charge of armament production at ministerial level and the former director of artillery General Louis Baquet was sent back to the front: in his eyes, a politician was "better armed than a general to sustain political assaults." ${ }^{46}$ In the summer of 1915, the French army started to reception new pieces of large caliber.

\footnotetext{
${ }^{44}$ For example [Lebon 1915, p. 220] and [Reinach 1916, p. 253-260]. See also the testimonies of the commanders, such as [Poincaré 1928, vol. 5, p. 333-334] or [Foch 1931, vol. 1, p. 19]. On the insufficencies of the 75 , see [Percin 1914, p. 264].

${ }^{45}$ See [Ripperger 1995], as well as [Bédier 1919, p. 147-157].

${ }^{46}$ [Baquet 1921, p. 15]. For an overview of the evolution of the materials in the artillery during the war, see [D'Aubigny 1921].
} 
While the strategic importance of artillery, and especially heavy artillery increased significantly, the tactical use of cannon underwent important changes as well. Anti-aircraft and anti-zeppelin firing, mountain engagements, and the general need of shooting from entrenched positions behind a protective monticulewhich was called indirect fire - required new procedures. In August 1915, General Frédéric-Georges Herr was put in charge of the defense of Verdun and suffered the full blow of the German offensive in February 1916. In 1912, Herr had observed the Balkan war and predicted many of the features of the war he was now fighting [Herr 1913]. By 1915 it had become clear to him that the main problem facing artillery no longer was a simple question of supply and materials: "a gigantic intellectual effort was required." In particular, shooting had become the focus of attention. "It had become necessary to [be able to] shoot on invisible objectives, during the night, and, in all circumstances, shots had to be of the utmost precision [...] so as not to hit friendly troops" [Herr1923, p. 39]. Now, to shoot accurately had become a complex technoscientific problem, which involved the identification of targets using sound ranging or aerial reconnaissance, their localization on largescale maps that needed to be produced in large quantities, the development of reliable telephonic communication between observers and gunners, better knowledge of meteorological data at various altitudes (wind, pressure and temperature), and precise firing tables. "Meteorology, acoustics, optics, cartography, what branch of science was not drafted in artillery's service?" [Bédier 1919, p. 180]. As a testimony of the importance conferred to artillery in the war, it is worth noting that, in all these areas, significant technological and scientific advances were made from 1914 to $1918 .^{47}$

The new guns required new firing tables. The new uses demanded that existing tables be extended to higher shooting angles. It had made sense to compute direct fire tables for guns to be used at sea, just as there was no harm in relying on timeconsuming procedures to adjust the fire of siege cannons. This was no longer the case. Information was needed about the whole trajectory of projectiles, and not just their range. Hence the change in terminology, whereby what used to be called "range tables" was now known as "firing tables". But ballistic military structures were totally unprepared to supply them. When war broke out in August 1914, Gâvre was no exception to this general trend. All but five officers deserted the proving ground and joined fighting units. For lack of personnel, most technical activities were abruptly interrupted and the five military engineers that remained desperately idling at Gâvre while their repeated requests to be reassigned to the front were being denied one after the other. ${ }^{48}$

To make matter worse, while the navy had paid small attention to ballistics, the land army had paid almost no attention to it. Before 1914, low regard, and indeed disdain, for ballistics was entrenched among artillerymen. ${ }^{49}$ Despite a rich tradition of ballistic studies, in the first decades of the century the Officers' Training School for Artillery and Engineering in Fontainebleau (the École d'application d'artillerie et du génie formerly located in Metz, mentioned earlier) allowed time

${ }^{47}$ On observation, see [Morgan 1959-1960]. On map-making, see [Laves 1919] and [Witherbotham 1919], as well as [Heffernan 1996]. On sound ranging, see note 7 above. On meteorology, see [Launay 1919] and [Launay 1922].

${ }^{48}$ [Patard 1930, p. 270n] and [Crémieux 1930, p. 158].

${ }^{49}$ See, e.g., [Baquet 1921], p. 28n and [Anonymous 1921]. 
for barely four lessons in the officers' training curriculum that were devoted to ballistics and the principles of firing tables. ${ }^{50} \mathrm{~A}$ conscript once complained that during instruction, "ballistics [was] nothing else than a soporific lesson in terminology" [Malloué 1911, p. 136]. As a result, the philosopher Alain who served in the artillery during WWI was hardly impressed by the mathematical skills of the polytechnicians he met on the front: "Our artillerymen seemed poor mathematicians to me." 51 More shockingly perhaps, among the staggering number of casualties there were not only young mathematicians who might later have turned out to be precious resources for ballistic work, but also fully-trained ballisticians whose expertise was accutely missed at Gâvre. Born in 1871, Commandant Henri Batailler had been in charge of the ballistics course at the Fontainebleau school and he had already published several articles on the topic in the Revue d'artillerie. But on 9 June, 1915, Commandant Batailler was killed on the Marne front. ${ }^{52}$

"Up until 1916, the artilleryman and the ballistician lived on knowledge acquired in peace time" [Boissonnet 1920, p. 41]. In fact, artillerymen in fighting units more often than not were forced to resort to their own means for improving the accuracy of their fire. On 9 September, 1914, Jules-Émile Henches wrote from the Marne front that "each day" he became more and more convinced that in the fighting "science is necessary, but its application must be [made] the simplest possible" [Henches 1918, p. 8]. ${ }^{53}$ "War," wrote the physicist and astronomer Charles Nordmann from the Paris Observatory, who actively served both in the artillery and on the board of inventions, "had ceased to be an art to become an experimental science like physics" [Nordmann 1917, p. 9]. ${ }^{54}$ The front itself was likened to a gigantic experiment in ballistics that should be exploited to increase shooting accuracy: "Because of the rich harvest in experimental shooting that everyone is able daily to reap on the front, firing tables produced before the war were found to hold insufficient, and even erroneous, information" [Herr1923, p. 40].

In fact, badly equipped experimental polygons sometimes lagged behind the front, notably in the study of atmospheric densities [Boissonnet 1920]. Using accurate ballistic coefficient (provided by ballisticians) and atmospheric studies made by the meteorologists enrolled by the army, fighting artillerymen were able to find inaccuracies in the Gâvre air resistance function, which had hitherto remained within the margin of errors. Frontline expertise was developed, with which ballisticians from the rear were hard pressed to compete. Reports had been written by officers on the front questioning either the accuracy of the air resistance function $F(v)$ or the firing tables themselves. Some officers were worried "not about the firing tables at their disposal, but also about those that can still be delivered to them, if they are computed on the basis of the present inaccuracies" ${ }^{55}$ A specialist

\footnotetext{
${ }^{50}$ [Challéat 1933-1935], vol. 2, p. 64, n. 1; see also p. 259; Challéat's course at Fontainebleau most probably condensed the lessons of his predecessor Chef d'escadron P. Henry who was among those who introduced Siacchi's methods in France [Henry 1894]. On ballistics at Metz and Fontainebleau, see [Bru 1996].

51 "Nos artilleurs m'ont paru assez peu géomètres" [Alain 1937, p. 115].

${ }^{52}$ [Sebert 1915]; see also Maurice Garnier, "Balistique extérieure" (conférences au Centre d'études tactiques d'artillerie de Metz), 3e éd. (avril 1920), SHD-Terre, 2W293, p. 8.

${ }^{53}$ Also interesting in regards to the scientific work of artillerymen on the front are the following testimonies: [Pastre 1918], [Lintier 1916], and [Cardot 1987].

${ }^{54}$ On Nordmann, see [Aubin, forthcoming 1].

55 "Quelques officiers [...] manifestent quelque inquiétude, non seulement sur les tables de tir dont ils disposent, mais sur celles qu'on peut encore leur délivrer, si elles sont calculés par les
} 
in anti-aircraft shooting since September 1914, Henches wrote from his command post he called "Aviatik-City" on 18 June 1915:

There have been concerning those airplane shootings papers overfilled with mathematics done by people who could never see that the instinct of a "hunting animal" is here necessary. They reach, for that matter, by very complicated, inapplicable processes, results that are close to, but not as valuable as, those I have been using for the last six months [Henches 1918, p. $59 \& 85] .^{56}$

On the front, artillery material was put to much more extensive testing than it ever was in polygons and in the process firing tables computed in the rear appeared defective. In a letter from General Curières de Castelnau written weeks before he was replaced by Philippe Pétain as the head of 2nd Army, it was stated that regulatory tables for the 75- $\mathrm{mm}$ cannon differed from nomograms (or abacs) given to motorized artillery sections. "These discordances not only concern trajectories corresponding to high angles but even trajectories that are regularly used" on the field. ${ }^{57}$ As a result, ommanding officers had their own tables of corrections, or networks of trajectories computed [Boissonnet 1920, p. 39]. Others designed special slide rulers or mechanical aiming device [Garnier 1922, p. 111]. Some artillery units lost confidence in the tables computed by theoretical means and corrected them on their own by experimental means. "Thus instead of having a single range table carefully established in the rear, there were many built with the help of a very large number of shots carried out in lousy experimental conditions." 58

The electric engineer Hippolyte Parodi, who would come to play an important part in computing new ballistic tables for the French army using graphical methods, underscored that he had first become aware of the initial insufficiency of firing tables while he was fighting on the front:

When I was called to the direction of the Service de balistique et de préparation des tables de tir, I had long been aware, according to the shots I had taken or controlled on the front, that the near totality of firing tables in use in the army were clearly false and that they had been established [...] through "archaic," inexact and simplified methods. ${ }^{59}$

errements actuels" [Garnier 1918a, p. 1]. This book which gathers various secret notes written during the war by Garnier can be found in various slightly different versions. I quote from one of the differing copies kept at the Bibliothèque nationale de france, in Paris, call number 8-V-42188.

${ }^{56}$ On the lack of practical knowledge of heavy artillery officers, see also ibid., p. 149-150.

${ }^{57}$ Général commandant la II ${ }^{\mathrm{e}}$ armée à $\mathrm{M}$. le colonel Leleu, chef de la section technique de l'artillerie, place Saint-Thomas d'Aquin, 19 May, 1915. SHD:Terre, 2W309

58" On l'a bien vu au cours de la guerre : il est arrivé souvent, en effet, qu'une batterie, avertie par des insuccès de l'inexactitude de sa table de tir établie par des procédés théoriques, l'a rectifiée expérimentalement sur le front. Ainsi, au lieu d'une seule table de tir bien établie à l'arrière, il y en avait plusieurs construites a l'aide de très nombreux tirs, faits dans de mauvaises conditions expérimentales et présentant souvent de gros inconvénients militaires." Lebesgue to Hadamard, 23 October 1919. AAS:Commission de la défense nationale, dossier "Ballistique."

59 "Quand j'ai été appelé à la direction du Service de balistique et de préparation des tables de tir, il y avait longtemps que je savais, d'après les tirs que j'avais dirigés ou contrôlés au front, que la presque totalité des tables de tir en usage aux Armées étaient nettement fausses et qu'elles avaient été établies [...] par des méthodes 'archaiques,' inexactes ou simplifiées." Parodi to Hadamard, 30 October, 1919. AAS, Commission de la défense nationale, dossier "Ballistique," emphasized by Parodi. On Parodi, see [Darrieus 1968] and [Merger 1994]. 
The tables, Parodi went on, were not only wrong; they were also inconsistent and self-contradictory. Some projectile might for example have for the same line of departure a greater range for a smaller initial velocity.

These errors and these incoherencies, which thankfully were uncovered only by a handful of artillery officers, were susceptible to arouse doubts in the mind of the combattants and to withdraw all confidence in the technical documents that were distributed to them... Yet, who knows whether by making some battery commanders excessively prudent this distrust would not have allowed at the beginning of the war to save precious human lives?" 60

Parodi's hopes notwithstanding, officers did notice deficiencies in firing tables. "Artillerymen demanded experimental firing tables, established by canon fire $[\grave{a}$ coups de canon]," not by theory which they distrusted [Boissonnet 1920, p. 40]. In the face of such criticism, professional ballisticians repeated that "exterior ballistics was before the war brought by the Gâvre Commission to a degree of perfection which fully satisfied all practical requirements" [Garnier 1918b, p. i] ${ }^{61}$ This meant that there existed accurate firing tables corresponding to initial speed up to $850 \mathrm{~m} / \mathrm{s}$ and initial angle up to $20^{\circ}$. But fighting officers sometimes not only questioned the accuracy of the firing tables they had at their disposal, but the very possibility of computing them with enough precision [Garnier 1918a]. At the Section technique de l'artillerie, Parodi concluded that many cannon shots were necessary to establish a firing table: "One should not forget that firing tables are only worth what the experiments used as basis for computations are worth, and that the mathematical apparatus [appareil mathématiques] in which they have been enclosed is incapable in itself of increasing their precision. Many cannon shots must be fired [Il faut consentir à tirer baucoup de coups de canon]"62. Even the mathematician Henri Lebesgue (1875-1941) who had collaborated with Parodi in the Mathematics Section placed under the under-secretary of inventions concurred: "What is this computing sickness, when experiments are (apparently), and in all cases can be, carried out. There certainly places in France where real shooting by $75 \mathrm{~s}$ is done $[. .$.$] and there is the front." 63$

The ballisticians at Gâvre therefore felt necessary to emphasize that the "mathematical toolbox [outillage mathématique]" they used was no "smokescreen [trompel'œil]" [Garnier 1918a, p. 8]. On the contrary, ballisticians emphasized, mathematics was indispensable for correctly evaluating perturbations depending on the particular circumstances of shooting. As the war unfolded, hopes indeed increased about the possibility of firing without preparation. Was it possible to open fire on a target, having allowed for all modifications due to the special circumstances by

60 "Ces erreurs et ces incohérences qui, heureusement n'ont été décelées que par un très petit nombre d'officiers d'artillerie, étaient de nature à porter le doute dans l'esprit du combattant et à lui enlever toute confiance dans les documents techniques qui lui ont été remis... Qui sait pourtant si cette défiance, en rendant systématiquement prudents certains commandants de batteries, n'aurait pas permis, au début de la guerre, d'économiser de précieuses vies humaines ?" Ibid.

${ }^{61}$ See also [Peira 1955, p. 36].

${ }^{62}$ Parodi to Hadamard, 30 October, 1919. AAS.

63 [Lebesgue 1991], letter CCXIII, p. 319; this letter is tentatively dated early 1915 by Pierre Dugac. On the Lebesgue-Borel correspondence during WWI, see [Gispert forthcoming]. 
means of computations, without any prior warning? This question had a solution and all belligerents were looking for it ever since the war had started.

\section{Scientific Work at Gâvre}

How the requirements of fighting artillerymen impacted the Gâvre Commission, and the specific role played by mathematicians over there remains to be examined. As was hinted at above, Gâvre was not the only institution involved in the French ballistic effort of 1915-1918. Under Parodi's energetic lead, the Calais Commission played a major part in the computing effort together with the Direction of Inventions (in which the Paris mathematicians Lebesgue and Montel were involved). To fulfill his tasks, Parodi suggested that high school teachers and university professors be mobilized for the task. More than 400 answered positively and about 300 effectively worked on the project. The team computed trajectories for every initial angle $\alpha$ multiple of $5^{\circ}$ from $0^{\circ}$ to $90^{\circ}$; for initial velocities varying from 0 to 1000 $\mathrm{m} / \mathrm{s}$ and for various values of ballistic coefficient [Ottenheimer 1924, p. 51-52]. Intense computational work was moreover carried out by the so-called "Commission ALVF" (heavy artillery on rail [artillerie lourde sur voie ferrée]), the committee in charge of organising railway artillery headed by Lieutenant-Colonel Girardville, which produced extensive tables giving range as a function of initial angle, initial velocity, and ballistic coefficient. Contrary to all previous practices, these tables, called the " $\left(\alpha, V_{0}, c\right)$ tables," were abstract constructs corresponding to no specific cannon or projectile. ${ }^{64}$ At Gâvre, the naval engineer Georges Sugot also introduced a new method to speed up computations, called the fictitious speed method [méthode des vitesses fictives] [Sugot 1918].

As was pointed out, all this work whose immediate usefulness was new questioned were only as good as the physical assumptions on which they were based. Knowledge of air resistance laws and the atmospheric density variation with respect to altitude might be improved with unknown effects on the computed tables. From both a mathematical and a practical point of view, it was the step-by-step method developed collaboratively by the mathematician Haag and the military ballistician Maurice Garnier that was the most innovative as well as the most lasting effort in ballistics during WWI.

On 16 June, 1917, Haag was assigned to the testing center of Vitry-le-François where he instructed training officers. On 29 November, he was promoted to the rank of lieutenant. In his commendation, Charbonnier wrote:

Ever since he arrived at Gâvre, M. Haag has studied the improvement and practical application of the new ballistic methods required by present shooting conditions, and especially by the problems of aerial shooting [...]. Monsieur Haag significantly contributed to this work and, among the important questions to whose solution he contributed I must name the following:

(1) the improvement of step-by-step computing processes;

(2) the invention and development of a computation method for differential coefficients;

\footnotetext{
${ }^{64}$ Etablished in 1916 by the war ministry the Commission ALVF had computed several general tables for angles of $22^{\circ}, 28^{\circ}, 33^{\circ}$ and $44^{\circ}$, with initial velocities between 300 to $900 \mathrm{~m} / \mathrm{s}$ and various ballistic coefficients. In 1919, the tables used the Gâvre air resistance law and a better estimate of the variation of atmospheric density with altitude [ALVF 1921].
} 
(3) new and original applications of probability theory to the determination of the detonation ellipses of projectiles with fuses. ${ }^{65}$

Charbonnier's commandation clearly distinguished between principal and secondary problems in ballistics, as well as problems linked with probability theory. After the war, Haag summarized some of his work on probability theory in a book by Borel's Treatise on Probabity [Haag 1926]. As we shall see below, Haag's contribution to secondary ballistic problems played a crucial part in increasing the accuracy of scientific shooting procedures. But from a mathematical point of view, it was his contribution to the principal problem of ballistics - to solve the hodograph - that is the most significant. In the following, we shall examine the mathematicians' work at Gâvre from two perspectives: (1) we will look in more detail at the specific ways in which Haag was able to work on and improve the step-by-step method that, as we have seen, can be dated back to Euler; and (2) we will review collaborative experimental and computing procedures followed at Gâvre and the role played by mathematicians in them.

4.1. The Theory of Errors. Already in the note he sent to the CRAS in 1915, Haag made an interesting innovation in exterior ballistics. Since in practice the knowledge of initial conditions were never known exactly, every gunner was perfectly aware of the need to determine the effects of small variations in the main three parameters: initial velocity, line of departure, and ballistic coefficient. This was usually done by simple interpolation in the tables. Alternatively, Siacci had analyzed the effect in the case of direct fire of substituting $V_{0}+\Delta V_{0}, \alpha+\delta \alpha$, and $c+\Delta c$ in the equation of the trajectory (equation 2.2). But no method existed to provide such estimates in the Eulerian step-by-step method to which one was forced to resort in the case of general trajectories, in particular the ones involved in airplane bombings with which Haag was at first concerned [Haag 1915a]. With his formal training in mathematical analysis, Haag was easily able to evaluate the size of the error without having to integrate the equation. ${ }^{66}$ In a formal analogy with celestial mechanics, he simply tracked down at any given order of approximation the errors thus produced. This is the work that had caught Charbonnier's eye.

When he reached Gâvre at the end of 1915, Haag undertook the systematic study of errors in ballistic theory. He was the first to work on this problem. He published his results after the war [Haag 1921]. In this account Eulerian integration methods produced two kinds of error. The ballistic error came from the

\footnotetext{
${ }^{65}$ Jules Haag's military file, SHD:Terre, 6Ye17966: "Depuis son arrivée à Gâvre, M. Haag a été employé à l'étude du perfectionnement et à la mise en application pratique des méthodes balistiques nouvelles qu'exigeaient les conditions de tir actuelles et en particulier les problèmes de tirs aériens, qui ont pris une importance si grande, aussi bien pour le Département de la Guerre que celui de la Marine.

Monsieur Haag a contribué dans une large mesure à ces travaux et, parmi les questions importantes à la solution desquelles il a collaboré, je dois citer les suivantes :

a) Amélioration des procédés de calculs des trajectoires par arcs successifs.

b) Élaboration et mise au point d'une méthode de calcul des coefficients différentiels.

c) Applications nouvelles et originales du calcul des probabilités à la détermination des ellipses d'éclatement des projectiles fusants."

${ }^{66}$ Note that Haag's work in ballistics is not directly related with his previous research in differential geometry. Supervised by Gaston Darboux, his Ph.D. thesis dealt with Lamé surfaces [Haag 1910].
} 


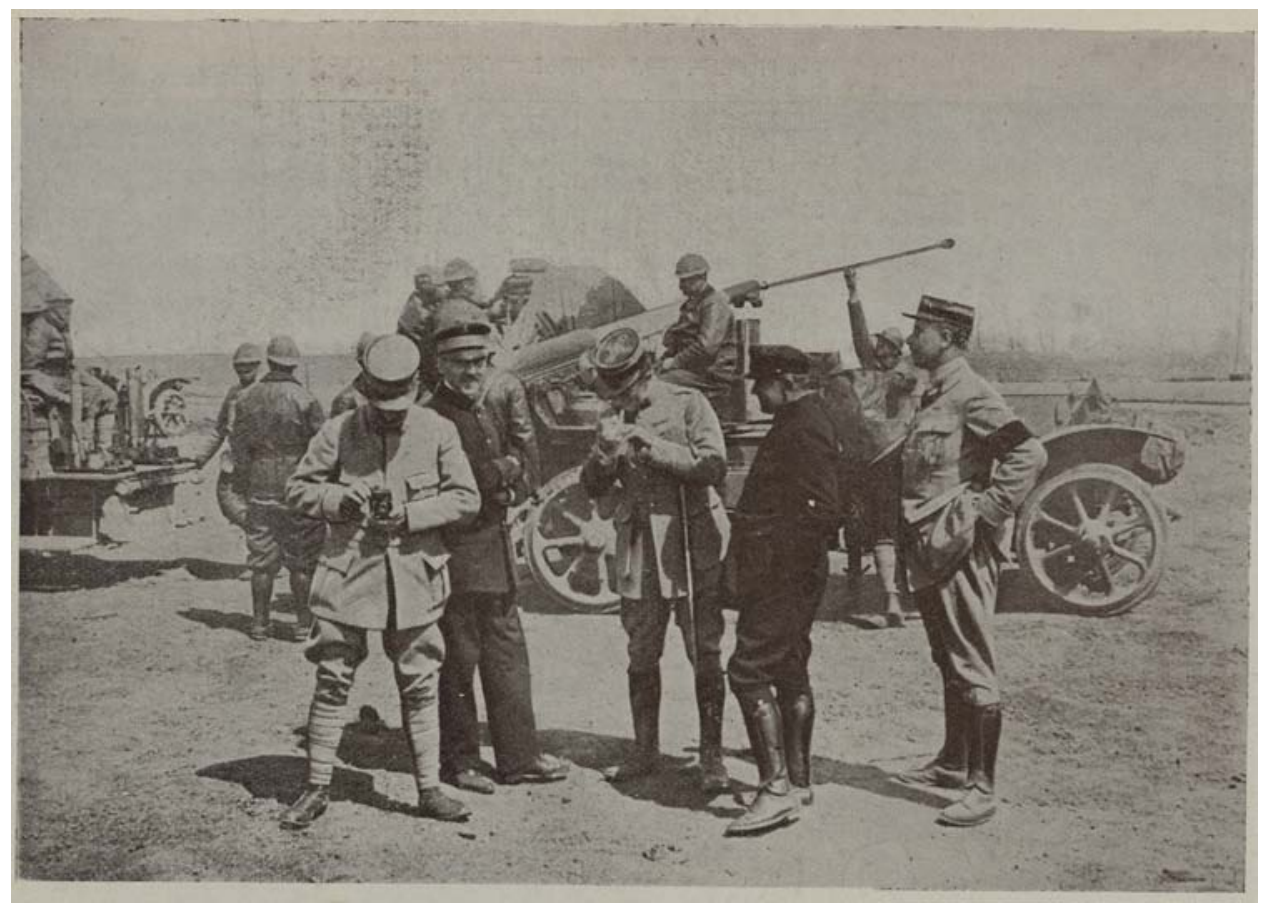

Figure 6. Preparing for aerial shooting at the training centre for practical anti-aircraft shooting in Arnouville, 1917. From left to right in the foreground, Jules Haag (taking a photo), Garnier, Pagézy (the head of the training centre), Rouch (head of the Army Meteorological Service) and and unidentified officer from the training center. (c) [Patard 1930], 288.

assumption that air resistance was quadratic over the small integration step. The geometric error was due to approximations in the method of integration. Assuming that the arc was infinitely small, Haag therefore produced a complete analysis of both types of error. Hopefully, this method would provide an estimate of the maximal arc lenths that gave the precision needed with the minimal computation time, allowing to speed up considerably the laborious process of computation. At Gâvre, piecewise integration procedures used the angle $\tau$ of the projectile velocity with respect to the horizontal as the independent variable, where Americans and British ballisticians instead chose time. Following an ad hoc rule, arcs were selected so that the angle decreased by less than $5^{\circ}$ and the velocity loss did not exceed 50 $\mathrm{m} / \mathrm{s}$ over the length of the arc. Using his method, Haag could show that this rule was no guarantee against imprecision or unefficiency: "parts of the trajectory are computed with a precision that is much too high, while others are with an insufficient precision" [Haag 1921, p. 21]. A new, more complicated rule was derived for determining the arcs for which the relative error remained smaller than $1 / 500$.

Together with the naval engineer Maurice Garnier, Haag applied this rule and designed a new computing procedure. Computing skeletons can be found in Haag's article [Haag 1921, p. 18-19, 27 \& 30]. Convergence radii of the expansion series were studied carefully to achieve the given precision. This at last provided a basis for 


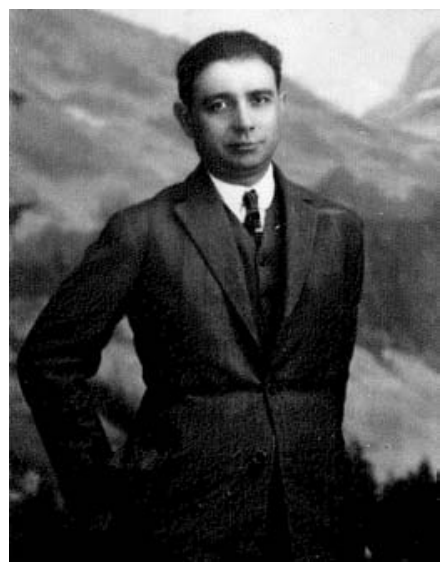

Figure 7. Osée Marcus in the 1920s. Courtesy of Simone Marcus.

making the "rational choice of the amplitude" of integration steps [Garnier 1922, p. 126]. This computing method was called the GH method (for Garnier-Haag) and presented in a special report in January 1917.

But this scientific method was not as efficient as one might have wanted. Later that year, the mathematics teacher [agrégé de mathématiques] Osée Marcus (figure 7) who was employed as a computer pointed out that computing procedures could be quickened by dispensing of the considerations of radii of convergence and by relying instead on simple Taylor approximations. Incorporating other minor points made by Captain Lévy (from the Mining Corps) ${ }^{67}$ and from Georges Valiron ${ }^{68}$, the GHM (Garnier-Haag-Marcus) method was adopted in September 1917 and remained in use until after World War II in France. ${ }^{69}$

Discussions about the approximation introduced by Marcus highlight a divergence of viewpoints between theory and practice:

In the case of pratical computations involving numerical integration, it is more often harmful than useful, more complicated than it is advantageous to perform the rigorous quadratures provided by analysis. Thus are we sometimes led to reject certain analytical formulae - no matter how elegant and seductive they may seem in a mathematician's eyes - to perform quadratures by simple approximation methods, apparently coarser, but in truth quicker and more precise [Garnier 1918b, p. vi].

\footnotetext{
${ }^{67}$ This probably is an allusion to the probability theorist Paul Lévy who was in the Mining Corps and an anti-aircraft officer during WWI. Although he served as an instructor at Arnouvillelès-Gonesses (figure 6) in 1916, Lévy was mobilized in a fighting unit for most of the war and did not mentioned his work at Gâvre in his autobiography [Lévy 1970, p. 54-55]. He is however mentioned in [Charbonnier 1928b, p. 580]

${ }^{68}$ Later a professor of analysis at the Sorbonne, Valiron was then a mathematics teacher at the lycée of Lyons (in the classes préparatoires). On the French system of higher education, see the contribution by Jean-Luc Chabert and Christian Gilain to this volume.

${ }^{69}$ In the GH method, the final velocity on the arc was first computed by approximating the arc as a parabola. The variations of the elements of motion $D s$ and $D \sigma$ were first computed by exact quadratures. $D x$ and $D y$ were approximately computed with $D s$ and $D t$ with $D \sigma$. In the GHM method, variations were computed directly using Tayor series and averages [Garnier 1918b].
} 


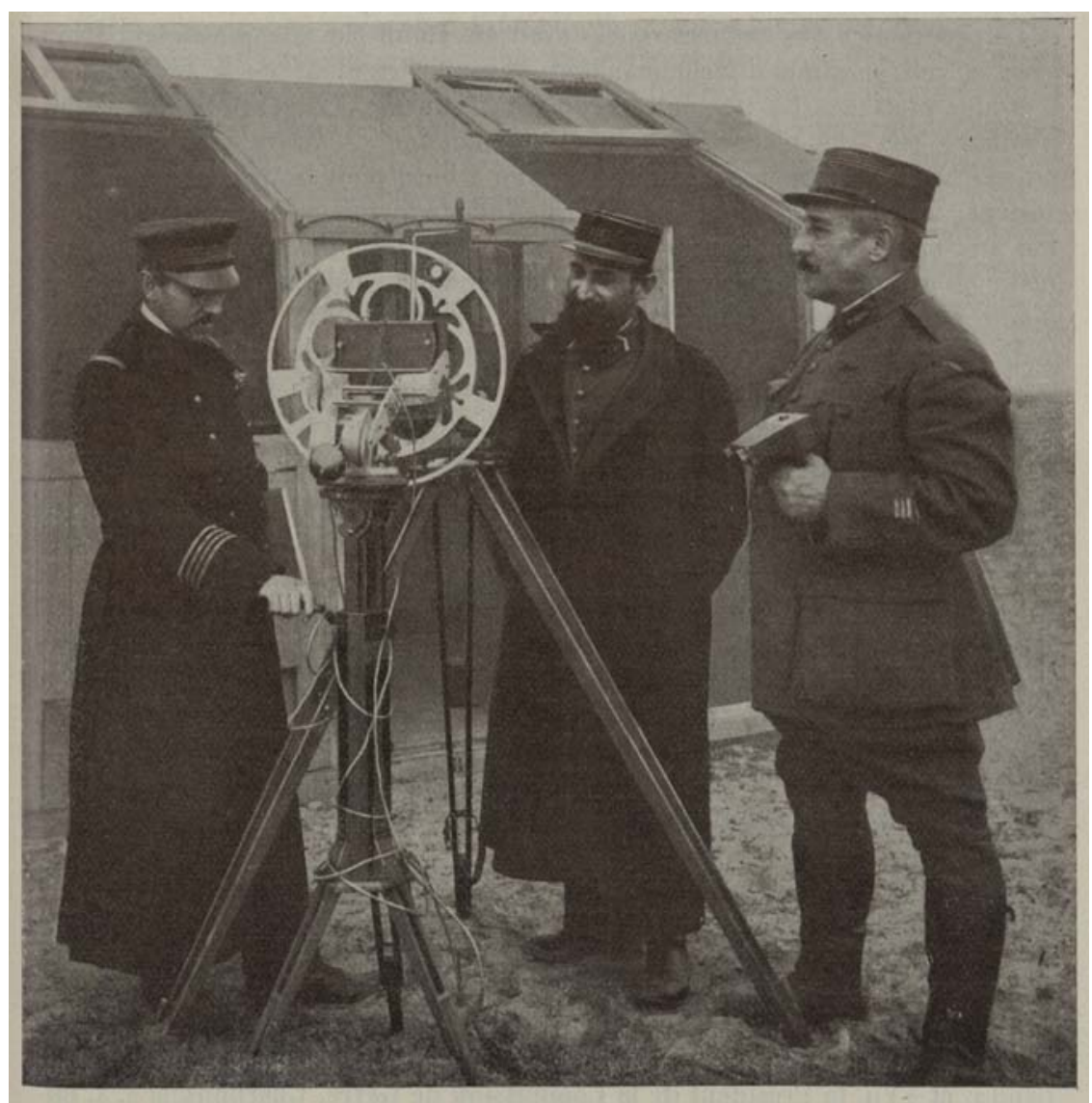

Figure 8. From left to right, Maurice Garnier, Louis Fort and Gustave Lyon with measuring instruments, undated. (c) [Patard 1930], 275.

As one can see, theses debates lay at the root of the later development of applied mathematics and numerical analysis.

4.2. Practical Work and Collaborative Procedures. At Gâvre, Haag's work took place in a special unit devoted to anti-aircraft gunnery. As discussed above, anti-aircraft gunnery posed a difficult challenge to older ballistic methods. It was the engineer Gustave Lyon (figure 8, on the right) who pushed for its creation. A polytechnician (X 1877) working as an acoustical engineer, Lyon had volunteered in 1914 and was soon in charge of the protection of the port of Cherbourg against airborne assaults. The Mission du tir aérien de Gâvre (MTAG) was set up under Lyon and Garnier's authority in April 1916. Soon, this "scientifico-technical organism" [Charbonnier 1928b, p. 580] counted a dozen mathematicians and physicists working under military guidance (table 1). Charbonnier described the procedure followed by the MTAG in a memo written in December 1917-which led to its formal establishment by the Navy Ministry, on 30 January, 1918, under the name 
of Mission balistique du tir aérien (MBTA), with a section based in Paris for theoretical investigations and another in Lorient in charge of experimental studies. ${ }^{70}$ It is interesting to examine the procedure outline by Charbonnier to get a precise understanding of the type of work mathematicians were doing at Gâvre.

First, for all types of guns and projectiles, the ballistic coefficient was evaluated with one or two shots. A network of 19 trajectories were completely computed using the labor-intensive arc method, and computed twice to insure that no mistake was made. The second step of the procedure was new with respect to previous customs. Extensive series of experiments were performed to measure the trajectory and duration of flight using a simplified theodolite designed by Lyon and a chronophotographic instument. This led to an immense amount of work. For 60 to 80 shots, 1,000 to 1,200 takes were taken that had to be analyzed. Atmospheric conditions were measured using weather balloons. Using all this material, the third step in the procedure consisted in preparing a corrected table using the computing method developed by Haag and Garnier. For each series of 9 shots, the piecewise integration had to be performed on about ten arcs. Finally, the MTAG produced networks of curves with shell trajectories and isochrone lines. "Refraining from imposing a method or an apparatus, the MTAG strictly limit itself to its ballistic role: to give combattants (Army and Navy) the networks they wanted." 71 This led them however to produce extensive networks: for the $75-\mathrm{mm}$ cannon, for example, it contained more than 40 sheets for each type of projectile.

Notes written for a series of experiments undertaken in the spring of 1916 can help to convey an even clearer sense of the mathematicians' activities at Gâvre. In one the notes written to prapare the experiments, Garnier wrote down very specific instructions: "In view of coordinating efforts in the best possible way and to achieve [our objectives] as fast as possible [...] I indicate in the following the detailed repartition of work." ${ }^{72}$ The workload was divided into field and office work. In the field, Garnier, another officer, and a soldier operated the battery; mathematicians (Haag and Châtelet), officers, workers, and apprentices manned three observations stations, while others tended the registering instrument (figure 8). In order to communicate between observation stations, mathematicians were asked to study the Morse code. ${ }^{73}$

The office work was also strictly divided among participants. Haag, for example, assisted by an apprentice named Guillaouic, was supposed to compute the fundamental trajectories and the differential coefficients allowing to correct trajectories for given experimental conditions, and on this basis draw the networks. Together with a military officer, Louis Fort, a mathematics teacher at the lycée of Neuilly, was assigned the task of preparing the shots and analyzing shooting conditions. On the chronophotographic plates, Fort was moreobver in charge of measuring the

\footnotetext{
${ }^{70}$ Charbonnier, Rapport No. 7, Note adressée à l'Ingénieur général, directeur central de l'Artillerie navale, 17 December, 1917. SHD:Terre, 10W73.

${ }^{71}$ Charbonnier, Rapport No. 7, p. 6. SHD:Terre, $10 \mathrm{~W} 73$.

72 "En vue de coordonner le mieux possible les efforts, pour aboutir dans les délais les plus rapides [...], j'indique ci-après la répartition détaillée du travail." Comptes-rendus de la Commission de Gâvre. Note no. 6, 29 May 1916. SHD:Terre, 10W73. This series of 13 numbered notes from May and June 1916 follow from the establishement of the MTAG in April 1916. All are signed by Garnier and can be found in SHD:Terre, 10 W73.

${ }^{73}$ Comptes-rendus de la Commission de Gâvre. Note no. 6, 29 May, 1916. \& note no. 9, 2 June, 1916. SHD:Terre, 10W73.
} 


\begin{tabular}{|c|c|c|}
\hline Name & Rank and title & Functions \\
\hline Châtelet & $\begin{array}{l}\text { 2nd-class officer in health } \\
\text { services; assistant professor } \\
\text { at university of Lille; } \\
\text { doctor of sciences }\end{array}$ & $\begin{array}{l}\text { First assigned to the MTAG } \\
\text { until Sept. 1917, then assistant } \\
\text { to naval engineer Anne: } \\
\text { helps with the preparation and } \\
\text { execution of shootings; } \\
\text { drafts reports and computations }\end{array}$ \\
\hline Denjoy & $\begin{array}{l}\text { Soldier in infantry; } \\
\text { doctor of sciences; professor } \\
\text { at university of Montpellier }\end{array}$ & General service \\
\hline $\begin{array}{l}\text { Ferdinand } \\
\text { Dreyfus }\end{array}$ & $\begin{array}{l}\text { Soldier in infantry; } \\
\text { bachelor in science } \\
\text { actuary at Ministry of Work }\end{array}$ & $\begin{array}{l}\text { Assistant to naval artillery } \\
\text { engineer Sugot: same } \\
\text { functions as Châtelet }\end{array}$ \\
\hline Fort & $\begin{array}{l}\text { Warrant officer in the infantry; } \\
\text { mathematics teacher at naval } \\
\text { school and lycée of Neuilly }\end{array}$ & $\begin{array}{l}\text { Preparation, execution, and } \\
\text { interpretation of aerial shootings }\end{array}$ \\
\hline Goullins & $\begin{array}{l}\text { Lieutenant in reserve } \\
\text { metropolitan artillery; } \\
\text { naval artillery engineer }\end{array}$ & $\begin{array}{l}\text { Helps with, then directs, shots; } \\
\text { main drafter of reports (flares } \\
\text { and incendiary shells) after } \\
\text { he becomes member of the } \\
\text { Commission in Sept. } 1917 . \\
\text { Assist. to Sugot on gunpowders }\end{array}$ \\
\hline Haag & $\begin{array}{l}\text { Second lieutenant in artillery; } \\
\text { professor at university of } \\
\text { Clermont-Ferrand }\end{array}$ & $\begin{array}{l}\text { Improvement and application } \\
\text { of new methods for } \\
\text { computing trajectories }\end{array}$ \\
\hline $\begin{array}{l}\text { Kampé de } \\
\text { Fériet }\end{array}$ & $\begin{array}{l}\text { Auxiliary in infantry; doctor of } \\
\text { sciences; assistant astronomer } \\
\text { at Paris Observatory }\end{array}$ & $\begin{array}{l}\text { Assistant to Sugot: helps with } \\
\text { shooting; drafts reports and } \\
\text { computations }\end{array}$ \\
\hline Marcus & $\begin{array}{l}\text { Ordnance soldier; } \\
\text { mathematics teacher }\end{array}$ & $\begin{array}{l}\text { Assistant to Garnier for } \\
\text { experiments and computing }\end{array}$ \\
\hline Pélissier & $\begin{array}{l}\text { Auxiliary in infantry, then } \\
\text { second lieutenant in artillery } \\
\text { student at École normale } \\
\text { supérieure }\end{array}$ & $\begin{array}{l}\text { Assistant to Anne; same } \\
\text { functions as Châtelet }\end{array}$ \\
\hline Sauvigny & $\begin{array}{l}\text { Temporary second lieutenant } \\
\text { in artillery; mathematics } \\
\text { teacher at lycée of Nancy }\end{array}$ & $\begin{array}{l}\text { Assistant to Anne; same } \\
\text { functions as Châtelet }\end{array}$ \\
\hline Valiron & $\begin{array}{l}\text { Soldier in the infantry; special } \\
\text { mathematics teacher at lycée } \\
\text { of Lyons }\end{array}$ & $\begin{array}{l}\text { Assistant to Garnier for } \\
\text { experiments and computing }\end{array}$ \\
\hline
\end{tabular}

TABLE 1. Mobilized Scientific Personal at the Gâvre Commission during WWI. From [Patard 1930, p. 277-278]. In addition, Ernest Esclangon, from the Bordeaux Observatory, and Gabriel Foëx, from Zürich, were present as non-mobilized scientific personal. 
Cartesian coordinates of every explosion of the fuses that were recorded. Assisted by an apprentice, Albert Châtelet, a maître de conférences at the university of Lille, was supposed to perform all the operations needed to draw isochrone lines on the networks. ${ }^{74}$

On 12 June, 1916, experiments had been performed and computational assignments were ready to be carried out. In a very explicit note report, Garnier listed all the operations that everyone had to do in sequence. ${ }^{75}$ But two weeks later, orders were modified due to changes in personnel and in priorities. All personnel not otherwise busy was to contribute to the computation of the networks under Haag's supervision. A 16-step procedure explained the work in an even more detailed manner. All apprentices received precise assignments; sample tables were drawn for computers to fill in; the number of copies to be made and the destination of each copy was specified; every computation and drawing to be done was described in detail. ${ }^{76}$

While military work at Gâvre may have seemed enviable compared to the lot of soldiers on the front, it was not without danger. In a talk delivered in Lille in 1924, Châtelet recalled an accident that occurred to him. In one of the shootings, observers placed behing the cannon observed huge red flares and abundant black smoke coming out of the mouthpiece that was expelling shades of shell for about one minute. The shell had exploded in the barrell and the cannoneers nowhere to hide: "I can insure you, even if this is not in the written report, that observers [...] felt that one minute can be very long." 77

From the minute description of the work done at Gâvre, one gets a rich impression of what it meant to use the mathematicians' skills in the First World War. We are far from the Romantic vision of genius solving a problem that had frustrated ignorant militarymen for ages. On the contrary, ballisticians at Gâvre had enough mathematical sophistication to be able to see the added value mathematicians were susceptible of bringing to their trade. It also seems clear that mathematicians were not "well prepared for their new role" [Patard 1930, p. 279] and that at first their experience at Gâvre may have been rather humbling. But in time, all could see how tight collaboration and division of labor was necessary for producing important results such as firing tables. Only then, could collaborative procedures drafted by ballisticians make room for mathematicians special abilities and sometimes assign them to positions of leadership.

4.3. Application to the Battlefield. Firing tables were not the end of the story. Artillerymen needed to be trained in order to make good use of it. In this, mathematicians had once again a crucial part to play. Officers testified that a "carnet de Haag" ([Boissonnet 1920], p. 39) circulated underground, one year

\footnotetext{
${ }^{74}$ In fact, Châtelet had been called to Lille on 5 August, 1914 and oly took up his position there in 1919. See [Condette 2009] and [Gauthier forthcoming].

${ }^{75}$ Comptes-rendus de la Commission de Gâvre. Note no. 12, 12 June, 1916. SHD:Terre, $10 \mathrm{~W} 73$.

${ }^{76}$ Comptes-rendus de la Commission de Gâvre. Note no. 16, 26 June, 1916. SHD:Terre, 10W73.

77 "je puis vous assurer, quoique ce ne soit pas sans le procès verbal, que les observateurs [...] trouvèrent qu'une minute, ça peut être très long." The typed text of Châtelet's speech with handwritten annotations can be found among his papers. Archives départementales du Pas-deCalais, Arras, 81 J 117. I wish to thank Sébastien Gauthier for making this document available to me.
} 


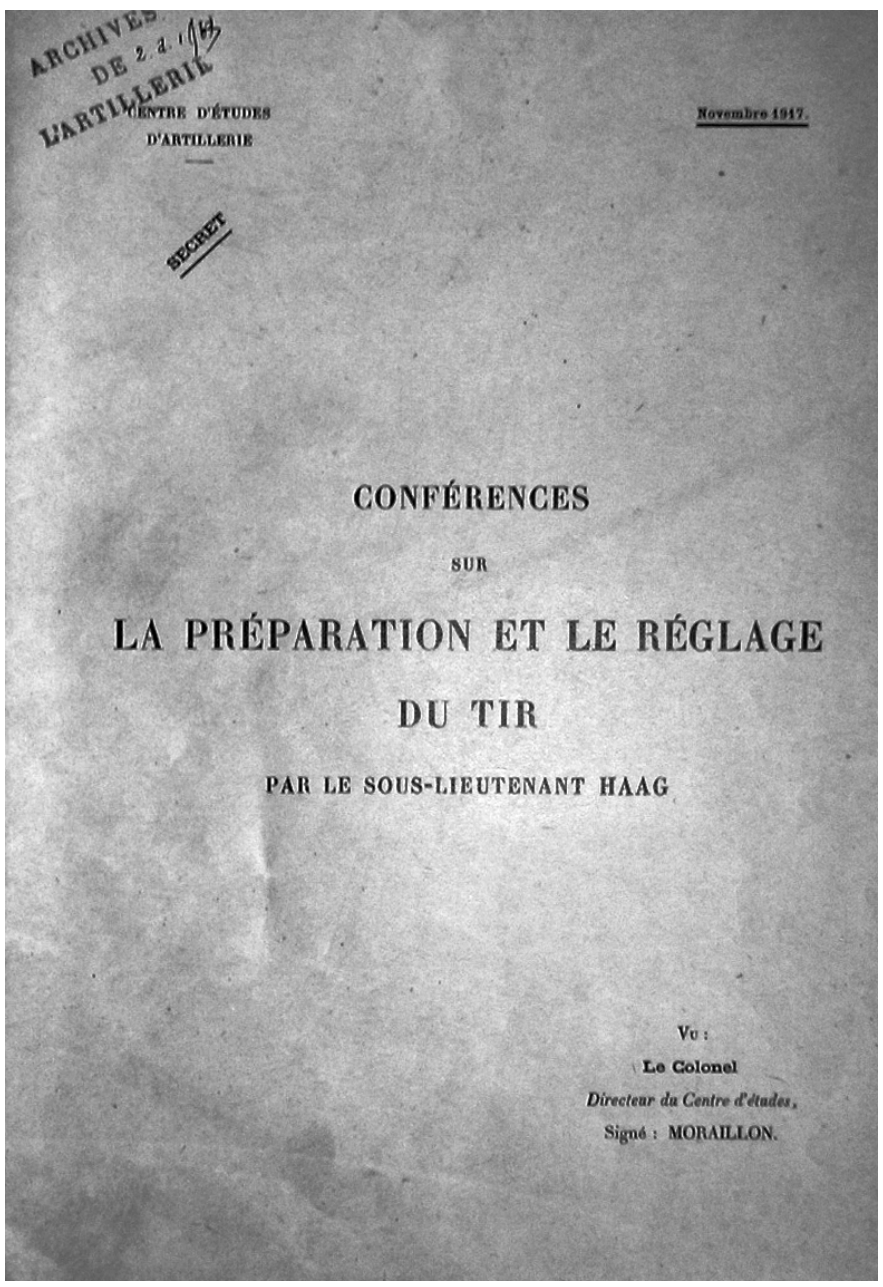

Figure 9. Le carnet de Haag: Haag's Course to Artillery Officers in Training [Haag 1917]

before it was printed and distributed officially (see figure 9). In this course designed for trainee officers, Haag wrote that the exact solution of the ballistic problem was a "chimera." But, he added, "one can as in all experimental problems look for an approximate solution. I will try to show you what is this solution and what is the degree of confidence we may grant to it." 78

In this course, Haag argued for the usefulness of the mathematical approach to the firing, which was presented as a mathematical problem. "Given a target, a cannon, [and] ammunition, it is asked to send one or several shells on the target,

\footnotetext{
78 "Le problème est ardu. La solution exacte est une chimère. Mais on peut, comme pour tous les problèmes d'ordre expérimental, en chercher une solution approchée. Je vais essayer de vous montrer en quoi consiste cette solution et quel est le degré de confiance qu'on peut lui accorder" [Haag 1917, p. 3].
} 


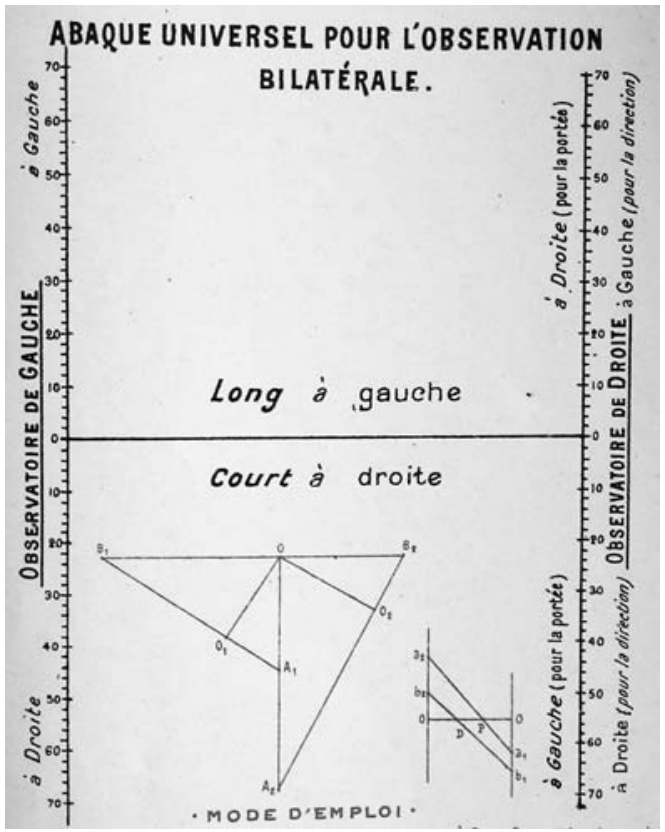

Figure 10. Nomogram used to adjust artillery fire developed by Haag during WWI. Repr. from [Haag 1917].

or at least in its immediate neighborhood."79 The problem had two solutions: the first was to fire several shots and observe the effect; the second was to prepare the shooting is such a way that the first shot fell if not on the target, but at least in its vicinity. If the first method was simpler and applicable without special training, if it did the trick for the daily operations of $75-\mathrm{mm}$ cannons, it was too expensive, too time-consuming as far as heavy artillery was concerned.

The various mathematical operations required in artillery and the different procedures developed on the field were evaluated in terms of the efficiency: computing in the command post, the use of double-entry tables for corrections, the manipulation of slide rulers, the considerations of graphs, and mechanical instruments. Figure 10 shows a nomogram prepared by the army in order to adjust the fire given two observers at different spots. 750 copies of this nomogram were produced by November 1917. But were they used? Haag's course clearly shows that the hierarchy seemed intent on increasing the mathematical level of artillerymen serving on the front.

Testimonies from men in the field show that this intention was not illusory. Take the case of the young Jean-Alexandre Cardot. He was merely 16 when war broke out and pursued his mathematical education in the trouble circumstances of the war. In 1917, he may have been among Haag's audience at the artillery school of Fontainebleau. He has given a vivid account of his first campain in a battery of $75 \mathrm{~s}$ in Lorraine in 1918. In Cardot's description, firing has indeed become a scientific exercise. Every targets are located on maps by their coordinates. Weather

79 "Étant donné un objectif, un canon, des munitions, il s'agit d'envoyer un ou plusieurs obus sur l'objectif, ou au moins dans un voisinage immédiat" [Haag 1917, p. 3]. 
reports transmit daily the force and direction of the wind. Communications between observers and cannoners are insured via the telephone. One day, he goes out with his lieutenant to test new shells that can reach a target at 11 kilometers. Cardot described firing manouvers in detail. He explained how he was asked to use simple mathematical instruments and computations. The lieutenant says to him: "You will direct the fire. [...] Go. Here's the firing table" [Cardot 1987, p. 65]. Although the lieutenant tried to trick him by handling the wrong table, Cardot is wiser and the German train in the far finally shot down.

At the level of the General Staff, scientific firing was now taken for granted. At the end of 1917, according to General Herr, "the time ha[d] come when the French artillery at long last found, if not a complete and definitive [answer], at least one that was precise enough to be applicable so forth." The solution to the problem of firing by surprise was "the scientific preparation of shooting [la préparation scientifique du tir]" [Herr1923, p. 93]. In October 1917, the French artillery was able to fire at night or in the fog: "a fearful innovation" (ibid., p 94). It now possessed:

a scientific shooting method [that allowed] to shoot under any whether condition, at any time, on every terrains, in all circumstances. [...] It [was] able to open fire almost instantaneously on any seen or unseen point merely identified by its coordinates on a map [ibid., p. 95].

By the end of the war, the French artillery was finally using "scientific ballistics" [Challéat 1933-1935, vol. 2, p. 314]. Those were "the French methods of firing" that American artillerymen were taught in 1917 [Grotelueschen 2001, p. 20]. Although less praised than tanks and less bedeviled than poison gas, the new firing methods played no small part in the outcome of the war and the cannon was called the "artisan of Victory" [Rouquerol 1920]. "It was the massive surprise action of our artillery which, from 18 July, 1918 onwards, insured the success of our great offensives until Germany's capitulation" [Campana 1923, p. 122]. Ballisticians, it would seemed, had successfuly fulfilled their mission. As we have argued, this success owed much to their ability to enroll the effective collaboration of some mathematicians.

\section{Mathematicians' Attitudes towards Ballistics}

After the war, ballisticians wished to assert the new scientific status of their trade. Charbonnier praised the progress on ballistics achieved by the "alliance, made by the war, of ballisticians and savants" (Charbonnier's preface in [Garnier 1918b, p. viii]). While it used to be the exclusive domain of engineers and technicians, ballistics had, he wanted to say, truly become a first-rank science. "Because of its own interest, as pure science as for national interest, ballistics deserves to become a topic of research for pure scientist as it once was." ${ }^{80}$ Mathematicians however appeared more circumspect about the mathematical value of wartime ballistic research. Asked by Jacques Hadamard to report on the ballistic computations in which he had taken part, Lebesgue wrote on 23 October, 1919:

\footnotetext{
${ }^{80}$ See Charbonnier's preface in [Garnier 1918b, p. viii]. Charbonnier reached again to mathematicians at the International Congress of Mathematicians in Toronto in 1920 [Charbonnier 1928b].
} 
such a report would perhaps be more pertinent if it were addressed to Committee awarding the prix de vertu [attributed at that time for the most courageous act on the part of a poor Frenchman], since none of those who worked on the construction of systems of ballistic trajectories claims to have done scientific work by performing numerical computations using well-know procedures; all merely tried to be useful. ${ }^{81}$

Lebesgue went on to explain that the team he headed (together with Montel) computed more than a thousand trajectories, each of them independently computed by two persons. This work, Lebesgue concluded, was useful because it allowed the quick construction of range tables at a time when few shooting tests could be carried out due to the overload of work encountered by proving grounds and military research institutions. "But the extent of the effort should not let one to think that the tool that was constructed is worth so much that it could be used for a long time to come." ${ }^{82}$ Recalling the two main uncertainties in ballistic theory (the air resistance law $F(v)$ and the air density law $\Delta(y)$ ), Lebesgue stated that no computation could compete with pure empiricism. Past experience during the war had shown that the latter method was simpler, cheaper, and more efficient from a military point of view.

Lebesgue's poor opinion about the value of computational ballistics was formed early on. Asked by Borel to get involved in both ballistics and sound-ranging studies, Lebesgue reluctantly agreed. "If this is useful to you, I am willing to do the computations. But then you have to tell me explicitly and in detail the operations I must carry out. I am willing to be a computing machine, but nothing less." He went on: "I will do the computations you ask in the manner of a stupid clerk; but nothing more." 83 As a result of this episode, relations soured between Borel and Lebesgue whose amour-propre seemed to have been hurt by Borel's managerial style. But I think that Lebesgue's reluctance which was due to many factors that were deeply personal to him was also the result of his very high ethical ground which forbade him to take credit he did not believed his war work had earned him. Lebesgue insisted that one should not put too much importance on the war contribution of the "Sorbonnoids" at the Bureau des calculs of the Division of Invention. ${ }^{84}$ His reticence toward computational ballistics was rooted in his lack of satisfaction with the experimental basis of theoretical ballistics. Alone among mathematicians who had taken part in the war effort, he underscored that "mathematics cannot create

\footnotetext{
81 "Un tel rapport serait peut-être plus légitime s'il était adressé à la Commission des prix de vertu, car aucun de ceux qui ont travaillé à la construction du réseau ne prétend avoir fait œuvre scientifique en effectuant des calculs numériques par des procédés bien connus ; tous se sont efforcés simplement d'être utiles." Lebesgue to Hadamard (23 October 1919). Archives AdS.

82 "Mais il ne faudrait pas que la grandeur de l'effort accompli fasse croire que l'outil construit a une valeur telle qu'on pourra l'employer encore longtemps." Lebesgue to Hadamard, 23 October 1919. AAS.

83 "Si cela vous est utile, je veux bien faire des calculs. Mais alors dîtes-moi expressément, et dans le détail, les opérations que je dois faire. Je veux bien être une machine à calcul, mais rien de plus. [...] Je ferai donc les calculs que vous me demandez à la façon d'un bon employé idiot ; rien de plus" [Lebesgue 1991], letter CCXIII, n.d., p. 318-319, In this correspondence with Borel, letters explicitly dealing war work are often undated; editors believe they can date them from early 1915.

${ }^{84}$ Lebesgue to Borel, letter n.d. [avril 1917], in [Lebesgue 1991], p. 339. On the fate of the friendship between Borel and Lebesgue during WWI, see [Gispert forthcoming].
} 
the world." In the absence of a solid experimental basis, Lebesgue thought, the time was not ripe for mathematical ballistics. ${ }^{85}$

During the war and after, Lebesgue's opinion about the value of the mathematical war effort varied little. He thought that in ballistics as well as in sound ranging, the physical problems overshadowed the mathematical effort. The only contribution mathematicians could make - and effectively made according to him - was to organize computing methods and their execution by technical assistants. However ingenious were the methods developed during the war (although Lebesgue hardly believed they were), this contribution would only last as long as deficient experimental bases would - not very long, Lebesgue thought.

Hadamard shared Lebesgue's opinion and was not overly impressed by the mathematics and science coming out of war work. As most commentators, he believed that the great scientific war was mostly one of application of known results rather than one of striking innovation. The ballistic papers he reviewed, he wrote, "for the most part bring, not scientific improvements concerning the principles, but rather modifications of purely technical nature aiming at applying these principles more or less easily in specific practical consequences. These are topics with which the Academy wishes to remain involved, but that nonetheless are on the sidelines of its proper function" ([Hadamard 1920], p. 437).

\section{Conclusion}

Our study has shown that, although it was not always trivial, the mathematics of ballistics was for the most part tedious. Mathematicians at Gâvre did work on topics that had some wider implications, but for the most part they were involved in menial tasks of experimentation, computation, and education. Still, their contribution to the war effort was significant, useful, and perhaps crucial to the final victory - and it was recognized as such. Ballisticians could legitimately pride themselves as having been able to use mathematicians' special abilities to their own ends.

Many prominent mathematicians were involved in ballistics during the war. To Lebesgue, Hadamard, Montel, and Drach already mentioned, we may add Arnaud Denjoy who worked on the solubility of the hodograph at Gâvre in July 1917, Ernest Vessiot, later to succeed Borel as director of École normale supérieure, and René Garnier who taught at the Sorbonne after the war. But the result was paradoxical. They were happy to close the parenthesis and leave behind the work that seemed most useful from a ballistic viewpoint, as it had seem to them rather trivial from a mathematical point of view. But of Drach's and Montel's work, most admired by Hadamard and which led to further work in the abstract theory of differential equations after the war, Charbonnier bluntly wrote: "this conquest, which honors the mathematicians, does not seem susceptible of providing ballisticians with new resources in view of applications" [Charbonnier 1928b, p. 574].

Yet, one wonders whether the ballistic experience of several French mathematicians and physicists did not have a deeper influence on the work they later did. Most mathematicians who were active at Gâvre indeed kept their connection to

\footnotetext{
85 "les mathématiques ne peuvent pas créer le monde; qu'elles ne peuvent suppléer l'expérience et l'observation mais, tout au plus, les résumer; que le moment n'est donc pas encore venu de faire de la balistique mathématique et que l'effort a faire actuellement est d'ordre expérimental" Lebesgue to Hadamard (23 October 1919). Archives AdS.
} 
the military research institution. In 1921, civilians joined the Commission for the first time since Hélie. Several mathematicians were nominated including Haag, Châtelet, Valiron, and Joseph Kampé de Fériet now at the university of Lille.

Some pure mathematicians never returned to their earlier concerns. Haag later became the director of the chronometric school in Besançon and produced some of the most important work in France on dynamical systems theory. Joining the Lille faculty, Kampé de Fériet became a specialist of fluid mechanics and a world leader in turbulence studies after World War II came back to pure mathematics following their stay in Gâvre. Also at Lille, Châtelet was so invested in the institutional rebuilding of his university that his mathematical research in number theory and algebra begun before the war was relegated to a minor place [Goldstein 2009]. The style of mathematical research this generation of mathematicians perperuated was characterized by very formal approaches of problems directly inspired by applications. ${ }^{86}$ Although they were pushed aside by the turbulent Bourbaki generation, these mathematicians planted the seeds of applied mathematics research in France.

\section{References}

[Alain 1937] Alain [Émile Chartier], Souvenirs de guerre, Paul Hartmann, Paris, 1937; pepr. "Les classiques de sciences sociales," UQAC, Chicoutimi, 2003.

[ALVF 1921] Ministère de la Guerre - Commission ALVF [Artilerie lourde sur voie ferrée], Tables de balistiques extérieure, 3 vols., no publ., 1921.

[Anonymous 1921] Anonymous [Gééral *** (sic)], Devant Saint-Mihel (1914), Archives de la Grande Guerre 8 (1921), p. 445-480.

[Aubin 2003] David Aubin, La Guerre du froid, la défaite de l'inventeur: bombes à oxygène liquide et production d'hélium, in [Aubin \& Bret 2003], p. 105-116.

[Aubin 2005] David Aubin, George David Birkhoff's Dynamical Systems (1927), Landmark Writings in Western Mathematics, 1640-1940, ed. Ivor Grattan-Guinness, Elsevier, Amsterdam, 2005, pp. 871-881.

[Aubin, forthcoming 1] David Aubin, Le coup d'œil du scarabée, in [Goldstein forthcoming].

[Aubin, forthcoming 2] David Aubin, 'Audacity or Precision': The Paradoxes of Henri Villat's Fluid Mechanics in Interwar France, to appear.

[Aubin \& Bret 2003] David Aubin and Patrice Bret, eds., Le Sabre et l'éprouvette: invention d'une science de guerre, 1914-1939, "14-18 Aujourd'hui," no. 6, Agnès Viénot, Paris, 2003.

[Aubin et al. 2010] David Aubin, Charlotte Bigg, \& H. Otto Sibum, eds., The Heavens on Earth: Observatories and Astronomy in Nineteenth-Century Science and Culture, Duke University Press, Durham, 2010.

[Baquet 1921] Louis Baquet, Souvenirs d'un directeur de l'Artillerie: les canons, les munitions, novembre 1914-mai 1915, Henri Charles-Lavauzelle, Paris, 1921.

[Baillot 2010] Rémi Baillot, Georges Claude, Le Génie fourvoyé : créateur de l'Air Liquide, du tube au néon, de l'énergie thermique des mers, EDP Sciences, Paris, 2010.

[Bédier 1919] Jospeh Bédier, L'Effort français : quelques aspects de la guerre, Renaissance du Livre, Paris, 1919.

[Belhoste 1990] Bruno Belhoste, J. V. Poncelet, les ingénieurs militaires et les roues hydrauliques, Cahiers d'histoire et de philosophie des sciences 29 (1990), p. 33-89.

[Belhoste \& Picon 1996] Bruno Belhoste and Antoine Picon, eds., L'École d'application de l'artillerie et du génie de Metz, 1802-1870: enseignement et recherches, Musée des plansreliefs, Paris, 1996.

[Bennett et al. 1956] Albert A. Bennett, William E. Milne and Harry Bateman, Numerical Integration of Differential Equations, Dover, New York, 1956. Repr. from a report Committee of the Division of Physical Sciences of the National Research Council, Bull N. R. C, 92, 1931.

[Bingen 1928] Bingen, Tables de calcul pour l'emploi de la méthode de Gâvre pour le calcul des trajectoires par arcs, Institut cartographique militaire, Bruxelles, 1928.

${ }^{86}$ The work of Hanri Villat in fluid mechanics, which rose to high prominence in interwar France, fitted squarely in these approaches. On this, see [Aubin, forthcoming 2]. 
[Boissonnet 1920] J. Boissonnet, Les tables de tir pendant la guerre: combattants et balisticiens, Revue d'artillerie, 86 (1920), p. 35-56 and 146-164.

[Bernhelm Booß-Bavnbek \& Jens Høyrup 2003] Bernhelm Booß-Bavnbek \& Jens Høyrup, eds., Mathematics and War, Birkhäuser, Basel, 2003.

[Bos 1923] Charles Bos, Les Leçons qu'il faut tirer de la guerre de 1914 à 1918, Archives de la Grande Guerre 16 (1920), p. 288-316.

[Bret 2002] Patrice Bret, L'État, l'armée, la science: l'invention de la recherche publique en France, 1763-1830, Presses universitaires de Rennes, Remes, 2002.

[Broglie 1953] Maurice de Broglie, Jules Haag, CRAS 236 (1953), p. 761-???.

[Bru 1996] Problème de l'efficacité du tir à l'école d'artillerie de Metz: aspects théoriques et expérimentaux, Mathématiques et sciences humaines 136 (1996), p. 29-42.

[Campana 1923] J. Campana, Les Progrès de l'artillerie: l'artillerie française pendant la guerre de 1914-1918, Lavauzelle, Paris, 1923.

[Cardot 1987] Jean-Alexandre Cardot, Artilleurs de campagne, 1918, La Pensée universelle, Paris 1987.

[Challéat 1933-1935] J. Challéat, L'Artillerie de Terre en France pendant un siècle : histoire technique (1816-1919), 2 vols., Charles Lavauzelles, Paris, suppl. to the Mémorial de l'artillerie française, 1933-1935.

[Chapeaux 2006] Antoine Chapeaux, Michelin et l'aviation, 1896-1945: patriotisme industriel et innovation, Lavauzelle, Paris, 2006.

[Charbonnier 1906] Prosper-Jules Charbonnier, Historique de la balistique extérieure à la commission de Gâvre, Revue maritime et coloniale 168 (1906), p. 411-476.

[Charbonnier 1907] Prosper-Jules Charbonnier, Balistique extérieure rationnelle, O. Douin, Paris, 1907.

[Charbonnier 1927] Prosper-Jules Charbonnier, Traité de balistique extérieure, 2 vols., GauthierVillars, Paris, 1927.

[Charbonnier 1928a] Prosper-Jules Charbonnier, Essais sur l'histoire de la balistique, Société d'éditions géographiques, maritimes et coloniales, Paris, 1928.

[Charbonnier 1928b] Prosper-Jules Charbonnier, Sur l'état actuel de la balistique extérieure théorique, Proceedings of the International Mathematical Congress Held in Toronto, August 11-16, 2 vols., ed. J. C. Fields, University of Toronto Press, Toronto, 1928, vol. 2, p. 571-594.

[Charbonnier 1929] Prosper-Jules Charbonnier, Notice sur les travaux scientifiques, GauthierVillars, Paris, 1929.

[Châtelet \& Chazy 1956] Albert Ch âtelet and Jean Chazy, Jules Haag, Annuaire de l'association amicale des anciens élèves de l'École normale supérieure, 1956, pp. 34-???

[Chéret 1990] Roger Chéret, The Life and Work of Pierre Henri Hugoniot, Shock compression of condensed matter 1989: Proceedings of the American Physical Scoiety Topical Conference held in Albuquerque, New Mexico, August 14-17, 1989, ed. S. C. Schmidt, J. N. Johnson \& L. W. Davison, North-Holland, Amsterdam, 1990, p. 12-19; repr. James N. Johnson \& Roger Chéret, eds., Classic Papers in Shock Compression Science, Springer, Berlin, 1998, p. $148-160$.

[Claude 1919] Georges Claude, Au creuset de la guerre: politiciens et Polytechniciens, private pub., Boulogne-sur-Seine, 1919.

[Collective 1922] La Dernière Lettre écrite par des soldats français tombés au champ d'honneur 1914-1918, choisies par des pères qui pleurent un enfant mort pour la France et par d'anciens combattants réunis sous la présidence de M. le maréchal Foch, Union des Pères et Mères dont les fils sont morts pour la Patrie, Ligue des Chefs de Section et des Soldats combattants \& E. Flammarion, Paris, 1922.

[Condette 2009] Jean-François Condette, Albert Châtelet: La République par l'école (1883-1960), Artois Presse Université, Arras, 2009.

[Cranz \& Vallier 1913] Carl Cranz and Emmanuel Vallier, Ballistique extérieure, in Encyclopédie des sciences mathématiques pures et appliquées, ed. Jules Molk and Paul Appell, tome IV, $6^{\mathrm{e}}$ volume, $1^{\text {er }}$ fascicule, Gauthier-Villars, Paris \& H. G. Teubner, Leipzig, 1913.

[Crémieux 1930] Maxime Crémieux, La Commission de Gâvre, Revue maritime et coloniale, $2^{\mathrm{e}}$ sem. (1930), p. 143-161.

[Darrieus 1968] Georges Darrieus, Notice nécrologique sur Hippolyte Parodi (1874-1968), Membre de la Division des Applications des sciences à l'industrie, CRAS 267 (1968), p. 81-86. 
[D'Aubigny 1921] D'Aubigny, Rapport sur les armements, Archives de la Grande Guerre 8 (1921), p. 493-536.

[Delauney 1892] Julien Delauney, Notice sur le professeur Hélie. Mémorial de l'artillerie de la marine 20 (1892), p. 788-794.

[Didion 1860] Isidore Didion, Traité de balistique, 2nd ed. J. Demaine, 1860; orig. publ. in 1848.

[Dodier \& Valiron 1927] H. Dodier and Georges Valiron, Calcul des trajectoires curvilignes par arcs et des altérations d'après les méthodes américaines, Mémorial de l'artillerie française 6 (1927), p. 425-471.

[Drach 1914] Jules Drach, Sur les équations différentielles du premier ordre et du premier degré, CRAS 158 (1914), p. 926-929.

[Drach 1920] Jules Drach, L'équation différentielle de la balistique extérieure et son intégration par quadratures, Annales scientifiques de l'École normale supérieure 37 (1920), p. 1-94.

[Epple et al. 2005] Moritz Epple, Andreas Karachalios, \& Volker R. Remmert, Aerodynamics and Mathematics in National Socialist Germany and Frascist Italy: A Comparison of Research Institutes, Osiris 20 (2005), p. 131-158.

[Foch 1903] Ferdinand Foch, Des principes de la guerre : conférences faites à l'École supérieure de guerre Berger-Levrault, Paris, 1903.

[Foch 1922] Ferdinand Foch, ed., La Dernière Lettre écrite par des soldats français tombés au champ d'honneur 1914-1918, choisies par des pères qui pleurent un enfant mort pour la France et par d'anciens combattants, Union des Pères et Mères dont les fils sont morts pour la Patrie, Ligue des Chefs de Section et des Soldats combattants \& E. Flammarion, Paris, 1922.

[Foch 1931] Ferdinand Foch, Mémoires pour servir à l'histoire de la guerre 1914-1918, 2 vols. Plon, Paris, 1931.

[Fontanon 2005] Claudine Fontanon, L'obus Chilowski et la soufflerie balistique de Paul Langevin. Une recherche militaire oubliée de la mobilisation scientifique (1915-1919), in Deux siècles d'histoire de l'armement. De Gribeauval à la force de frappe, ed. Dominique Pestre, CNRS éd., Paris, p. 81-110.

[Galvez-Behar 2008] Gabriel Galvez-Behar, La République des inventeyrs: propriété et organisation de l'innovation en France (1791-1922), Coll. "Carnot," Presses universitaires de Rennes, 2008.

[Garnier 1918a] Maurice Garnier, Note technique $n^{\circ}$ 2 : définition et détermination du coefficient balistique, tables de tir (tableau principal et tableaux de correction), dated 27 March, 1918, p. 1. SHD:Terre, 10W73.

[Garnier 1918b] Maurice Garnier, Balistique extérieure: calcul des trajectoires par arcs successifs Gauthier-Villars, Paris, 1918.

[Garnier 1922] Maurice Garnier, Conférences sur la balistique extérieure, Mémorial de l'artillerie française 1 (1922), p. 109-185.

[Gascouin 1920] Gascouin, L'Évolution de l'artillerie pendant la guerre Flammarion, Paris, 1920.

[Gauthier forthcoming] Sébastien Gauthier, in Goldstein-forthcoming.

[Gâvre 1916] Commission de Gâvre, Tables balistiques de la Commission de Gâvre 1. Tir de plein fouet, Imprimerie des constructions navales, Lorient, 1916

[Gilman 1905] Franck Gilman, The Ballistic Problem, Annals of Mathematics 6 (1905), p. 79-89.

[Gispert forthcoming] Hélène Gispert, in Goldstein-forthcoming.

[Gladden 1930] Private E. N. Gladden, "Memoirs \& diaries: at Messines Ridge in 1917," http://www.firstworldwar.com/diaries/atmessinesridge.htm (viewed on 22 November, 2007), first published in Everyman at war: sixty personal narratives of the war, ed. Charles Benjamin Purdom, J. M. Dent, London, 1930.

[Glück 1919] G. Glück, L'artillerie lourde pendant la guerre, Mercure de France 131 (1919), p. $444-456$

[Goldstein 2009] Catherine Golstein, La théorie des nombres en France dans l'entre-deux-guerres : de quelques effets de la première guerre mondiale, Revue d'histoire des sciences 62-1 (2009), p. $143-175$.

[Goldstein forthcoming] Catherine Goldstein \& David Aubin, La Grande Guerre des mathématiciens français, forthcomig.

[Grotelueschen 2001] Mark E. Grotelueschen, Doctrine Under Trial: American Artillery Employment in World War I, Greenwood Press, Westport, Conn., 2001. 
[Haag 1910] Jules Haag, Familles de Lamé de surfaces égales : généralisation et applications, Annales scientifiques de l'École normale supérieures 27 (1910), p. 257-337.

[Haag 1915a] Jules Haag, Sur un système de formules différentielles concernant les éléments de tir d'un projectile soumis à une résistance quadratique de l'air, CRAS 161 (1915), p. 379-381.

[Haag 1915b] Jules Haag, Sur la méthode d'Otto, CRAS 161 (1915), p. 524-526.

[Haag 1915c] Jules Haag, Sur le calcul du temps, CRAS 161 (1915), p. 633-634.

[Haag 1917] Jules Haag, Conférences sur la préparation et le réglage du tir, Centre d'études d'artillerie, November 1917. SHD:Terre, 2W292.

[Haag 1921] Jules Haag, Sur le calcul des trajectoires et de leurs altérations, Journal de l'École polytechnique 21 (1921), p. 1-52.

[Haag 1926] Jules Haag, Applications au tir, Gauthier-Villars, Paris, 1926 [= vol. 4 of Émile Borel's Traité des probabilités et de ses applications].)

[Hadamard 1920] Jacques Hadamard, Rapport sur les travaux examinés et retenus par la Commission de Balistique pendant la durée de la guerre, CRAS 170 (1920), p. 436-445.

[Hall 1952] A. Rupert Hall, Ballistics in the Seventeenth Century: A Study of the Relation of Science and War with Reference Principally to England, Cambridge University Press, Cambridge, 1952

[Hartcup 1988] Guy Hartcup, The War of Invention: Scientific Development, 1914-18, Brassey's Defence Publ., London, 1988.

[Heffernan 1996] Michael Heffernan, Geography, Cartography, and Military Intelligence: The Royal Geographical Society and the First World War, Transactions of the Institute of British Geographers 21 (1996), p. 504-533.

[Hélie 1865] Félix Hélie, Traité de balistique expérimentale: Exposé général des principales expériences d'artillerie executes à Gâvre de 1830 à 1864 J. Dumaine, Paris, 1865.

[Hélie \& Hugoniot 1884] Félix Hélie \& Pierre-Henry Hugoniot, Traité de balistique expérimentale, 2nd ed., 2 vols., Gauthier-Villars, Paris, 1884.

[Henches 1918] Jules-Émile Henches, À l'école de la guerre : lettres d'un artilleur (août 1914octobre 1916), Hachette, Paris, 1918.

[Henry 1894] P. Henry, Balistique extérieure: cours d'artillerie de l'École d'application de l'artillerie et du génie, lithograph, 1894.

[Herr 1913] Frédéric-Georges Herr, [Rapport des Balkans], in Revue d'artillerie, 15 février 1913.

[Herr1923] Frédéric-Georges Herr, L'Artillerie, ce qu'elle a été, ce qu'elle est, ce qu'elle doit être, Berger-Levrault, Paris, 1923.

[Hill n.d.] Archibald V. Hill, Memories and Reflections, 3 vols., Churchill College Archives, 920 HIL.

[Houllevigue 1914] Houllevigue, Le Canon française de 75, Revue de Paris (1914), ???

[Hull 1999] Andrew Hull, War of words: the public science of the British scientific community and the origins of the Department of Scientific and Industrial Research, 1914-16, British Journal for the History of Science 32 (1999), p. 461-481.

[Jones 1921-1922] E. Lancaster Jones, Sound-ranging, Proceedings of the Musical Association 48 (1921-1922), p. 77-89.

[Kevles 1968] Daniel J. Kevles, George Ellery Hale, the First World War, and the advancement of science in America, Isis 59 (1968), p. 427-437.

[Kevles 1969] Daniel J. Kevles, Flash and Sound in the A[merican] E[xpeditionary] F[orce]: The History of a Technical Service," Military Affairs 33 (1969), p. 374-384.

[Kevles 1978] Daniel J. Kevles, The Physicists: The History of a Scientific Community in Modern America, Alfred A. Knopf, London, 1978.

[L.G. 1931] L. G., Review of [Charbonnier 1928a], Isis 15 (1931), p. 376-380.

[Langlois 1892] Hippolyte Langlois, L'Artillerie de campagne en liaison avec les autres armes, 3 vols. L. Baudouin, Paris, 1892.

[Langlois 1906] Hippolyte Langlois, Question de défense nationale, Berger-Levrault, Paris, 1906.

[Launay 1919] Roland Bréauté [Robert Launay], Un universitaire aux Armées, Brossard, Paris, 1919.

[Launay 1922] Robert Launay, La météorologie pendant la Grande Guerre, Archives de la Grande Guerre 12 (1922), p. 695-704.

[Laves 1919] Kurt Laves, How the Map-Problem was Solved during the War, American Mathematical Monthly 26 (1919), p. 181-187. 
[Lebesgue 1991] Henri Lebesgue, Lettres d'Henri Lebesgue à Émile Borel, Cahiers du séminaire d'histoire des mathématiques 12 (1991), p. 1-506.

[Lebon 1915] Gustave Lebon, Enseignements psychologiques de la guerre européenne, Flammarion, Paris, 1915.

[Lecornu 1924] Léon Lecornu, Applications diverses à la mécanique, Bull. Soc. math. France 52 (1924), p. 36-40.

[Lévy 1970] Paul Lévy, Quelques aspects de la pensée d'un mathématicien, Blanchard, Paris, 1970.

[Lintier 1916] Paul Lintier, Avec une batterie de 75: ma pièce. Souvenirs d'un canonnier 1914, Plon-Nourrit, Paris, 1916; repr. L'Oiseau de Minerve, 1998.

[Long \& Weiss 1999] Lyle N. Long and Howard Weiss, The velocity dependence of aerodynamic drag: a primer for mathematicians, American Mathematical Monthly 106, No. 2 (February 1999), p. $127-135$.

[MacLeod \& Andrews 1971] Roy MacLeod \& E. K. Andrews, Scientific advice for the war at sea, 1915-1917: the Board of Invention and Research, Journal of Contemporary History 6 (1971), p. $3-40$.

[Malloué 1911] Armand Malloué, Comment on prend la ligne de mire, Culture physique 8 (1911), p. $136-138$.

[Mehrtens 1996] Herbert Mehrtens, Mathematics and War: Germany, 1900-1945, in National Military Establishments and the Advancement of Science and Technology, ed. Paul Forman \& José M. Sánchez-Ron, Amsterdam: Kluwer, 1996, p. 87-134.

[Merger 1994] M. Merger, Parodi, Hippolyte (1874-1955), professeur d'électricité appliquée, s.v. in Les professeurs du CNAM: Dictionnaire biographique 1794-1955, ed. Claudine Fontanon \& André Grelon, INRP \& CNAM, Paris, 1994, p. pages???.

[Merton 1942] Robert Merton, Science and Technology in a Democratic Order, Journal of Legal and Political Sociology 1 (1942), p. 115-126; repr. "The Ethos of Science," in R. Merton, On Social Structure and Science, University of Chicago Press, Chicago, 1996, p. 267-276.

[Mesnage 1953] P. Mesnage, La vie et l'œuvre de Jules Haag, Annales françaises de chronométrie 7 (1953), p. 141-???.

[Meyer 1996] C. Meyer, Jules Haag, Dictionnaire de biographie française 17 (1996), p. 444-???.

[Morel 1904] Marie-Auguste Morel, La Balistique graphique et son application dans le calcul des tables de tir, Gauthier-Villars, Paris, 1904.

[Morgan 1959-1960] Prentice G. Morgan, The Forward Observer, Military Affairs 23 (1959-1960), p. $209-212$

[Morin \& Tresca 1860] Arthur Morin and Henri-Édouard Tresca, Leçons de mécanique pratique, 3rd ed., Hachette, Paris, 1860.

[Mounier-Kuhn 2010] Pierre Mounier-Kuhn, L'informatique en France de la seconde guerre mondiale au Plan Calcul : l'émergence d'une science, Presses universitaires de Paris-Sorbonne, Paris, 2010.

[Nordmann 1917] Charles Nordmann, À coups de canons: notes d'un combattant Perrin, Paris, 1917.

[Ottenheimer 1924] J. Ottenheimer, Balistique extérieure, Armand Colin, Paris, 1924.

[P.N. 1907] Commandant P.N., Notre artillerie et les sanctions de la dernière guerre, Revue militaire générale 5 (1907), p. 534-561.

[Palazzo 1999] Albert P. Palazzo, The British Army's Counter-Battery Staff Office and Control of the Enemy in World War I, Journal of military history 63 (1999), p. 55-74.

[Parshall 2000] Karen H. Parshall, Perspectives on American Mathematics, Bull. Amer. Math. Soc. 37 (2000), p. 381-405.

[Parshall \& Rowe 1994] Karen H. Parshall and David E. Rowe, The Emergence of the American Mathematical Research Community, 1876-1900: J. J. Sylvester, Felix Klein, and E. H. Moore American Mathematical Society \& London Mathematical Society, Providence \& London, 1994.

[Pastre 1918] J. L. Gaston Pastre, Trois ans de front : Belgique, Aisne et Champagne, Verdun, Argonne, Lorraine. Notes et impressions d'un artilleur Berger-Levrault, Paris \& Nancy, 1918; repr. Presses universitaire de Nancy \& Secrétariat d'État chargé des anciens combattants et des victimes de guerre, Nancy, 1990.

[Patard 1930] Léon Patard, Historique de la Commission d'expériences de Gâvre (1829-1930), suppl. Mémorial de l'artillerie franạise, Impr. nationale, Paris, 1930. 
[Pattison 1983] Michael Pattison, Scientists, inventors and the military in Britain, 1915-19: the Munitions Inventions Department, Social Studies of Science 13 (1983), p. 521-568.

[Peira 1955] Pierre Peira, Historique de la conduite du tir dans la marine, 1900-1940, éd. Mémorial de l'artillerie française, 1955.

[Percin 1914] Alexandre Percin, Le Combat, F. Alcan, Paris, 1914.

[Poincaré 1928] Raymond Poincaré, Au service de la France : neuf années de souvenirs, 10 vols., Plon, Paris, 1928.

[Poyen-Bellisle 1889-1893] Henri de Poyen-Bellisle, Notice historique sur la Commission d'expérience de $G$ âvre, Revue maritime et coloniale 101 (1889), p. 312-329; 102 (1889), p. 32-51 and 377-391; and 116 (1893), p. 487-519.

[Reinach 1916] Joseph Reinach, La Guerre sur le front occidental : étude stratégique 1914-1915 Charpentier, Paris, 1916.

[Ripperger 1995] Robert M. Ripperger, The Development of the French Artillery for the Offensive, 1890-1914, Journal of Military History 59 (1995), p. 599-618.

[Rouquerol 1914] Gabriel Rouquerol, Méconnaissance du rôle et de la puissance de l'artillerie, Revue militaire générale (juillet 1914) ???.

[Rouquerol 1919] Gabriel Rouquerol, Après la victoire : notes et critiques Berger-Levrault, Nancy, Paris, \& Strasbourg, 1919.

[Rouquerol 1920] Gabriel Rouquerol, Le Canon : artisan de la victoire, Berger-Levrault, Nancy, Paris, \& Strasbourg, 1920.

[Roussel 1989] Yves Roussel, Histoire d'une politique des inventions, 1887-1918, Cahiers pour l'histoire du CNRS 3 (1989), p. 19-57.

[Sainean 1916] Lazare Sainean, L'Argot des tranchées : d'après les lettres des poilus et les journaux du front Paris, 1919; repr. Slatkine, Geneva, 1973.

[Schiavon 2003a] Martina Schiavon, Itinéraires de la précision : géodésiens, artilleurs, savants et fabricants d'instruments en France, 1870-1930 (environ), doctoral thesis, ÉHESS, Paris, 2003.

[Schiavon 2003b] Schiavon, Martina, Des savants-officiers entre science, armée, État et industrie de précision : les géodésiens du Service géographique de l'Armée, 1887-1920, in [Aubin \& Bret 2003], p. 60-73.

[Schwartz 1927] Philip Schwartz, La balistique appliquée au Etats-Unis: étude critique des progrès réalisés en balistique appliquée par le département de l'artillerie de l'armée des Etats-Unis depuis 1917, Mémorial de l'artillerie française 6 (1927), p. pages???.

[Sebert 1915] Hippolyte Sebert, Rapport sur les travaux de M. le commandant Batailler, CRAS 161 (1915), p. 895-897.

[Seddik-Ameur 2003] Nacira Hadjadji Seddik-Ameur, Les tests de normalité de Lhoste, Mathématiques et sciences humaines 162 (2003), p. 19-43.

[Siacci 1892] Francesco Siacci, Balistique extérieure, trans. P. Laurent Berger-Levrault, Paris \& Nancy, 1892

[Siegmund-Schultze 2003] Reinhard Siegmund-Schultze, Military Work in Mathematics 1914-1945: An Attempt at an International Perspective, in [Bernhelm Booß-Bavnbek \& Jens Høyrup 2003], p. 23-82.

[Smith 1990] Meg Weston Smith, E. A. Milne and the Creation of Air Defence: Some Letters from an Unprincipled Brigand, 1916-1919, Notes and Records of the Royal Society of London 44 (1990), p. 241-255.

[Steele 1994] Brett D. Steele, Muskets and Pendulums: Benjamin Robins, Leonhard Euler, and the Ballistic Revolution, Technology and Culture 35 (1994), p. 348-382.

[Steele \& Dorland 2005] Brett D. Steele and Tamara Dorland, eds., The Heirs of Archimedes: Science and the Art of War through the Age of the Enlightenment The MIT Press, Cambridge, Mass., 2005.

[Sugot 1918] Georges Sugot, Cours de balistique: École d'application de l'artillerie navale, Imprimerie nationale, Paris, 1918.

[Tournès 2010] Dominique Tournès, "Off the Target?: Exact Solution to Approximate Differential Equations in 18th- and 19th-Century Ballistics," unpublished talk at the conference "In duplicata ratione velocitatis...: Fluid Resistance from Newton to the Present," Paris, 29-30 October 2010, and at HSS Annual Meeting, Montreal, 4-7 November, 2010.

[U.S. n.d.] U.S. Government, Aberdeen Proving Ground, Ballisticians in War and Peace, vol. 1: A History of the United States Army Ballistics Research Laboratories 1914-1956, n.d. 
[Vallier 1915] EmmanuelVallier, Le tir indirect en 1915, Revue générale des sciences pures et appliquées 16 (1915), p. 297-299.

[Warwick 1995] Andrew Warwick, The Laboratory of Theory, or What's Exact About the Exact Sciences? in The Values of Precision, ed. M. Norton Wise, Princeton University Press, Princeton, 1995, p. 311-351.

[Witherbotham 1919] H. S. L. Witherbotham, Geographical work with the Army in France, Geographical Journal 54 (1919), p. 12-23.

[Ziman 2000] John Ziman, Real science: What it is and what it means, Cambridge Univ. Press, Cambridge, 2000.

David Aubin, Université Pierre et Marie Curie, Institut de mathématiques de Jussieu, 4 Place Jussieu, 75252 Paris Cedex 05, France

E-mail address: david.aubin@upmc.fr 